\title{
Intercomparison of stratospheric ozone profiles for the assessment of the upgraded GROMOS radiometer at Bern
}

S. Studer ${ }^{1,2}$, K. Hocke ${ }^{1,2}$, M. Pastel ${ }^{3}$, S. Godin-Beekmann ${ }^{3}$, and N. Kämpfer ${ }^{1,2}$

${ }^{1}$ Institute of Applied Physics (IAP), University of Bern, Bern, Switzerland

${ }^{2}$ Oeschger Center for Climate Change Research (OCCR), University of Bern, Bern, Switzerland

${ }^{3}$ Laboratoire Atmosphères, Milieux, Observations Spatiales (LATMOS), Université de Versailles, Saint-Quentin-en-Yvelines, Guyancourt, France

Received: 28 May 2013 - Accepted: 25 June 2013 - Published: 4 July 2013

Correspondence to: S. Studer (simone.studer@iap.unibe.ch)

Published by Copernicus Publications on behalf of the European Geosciences Union.

Intercomparison of stratospheric ozone profiles

S. Studer et al.

\section{Title Page}

\section{Full Screen / Esc}

Printer-friendly Version

Interactive Discussion

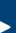

ose 


\section{Abstract}

Since November 1994, the GROund-based Millimeter-wave Ozone Spectrometer (GROMOS) measures stratospheric and lower mesospheric ozone in Bern, Switzerland $\left(47.95^{\circ} \mathrm{N}, 7.44^{\circ} \mathrm{E}\right)$. GROMOS is part of the Network for the Detection of Atmo5 spheric Composition Change (NDACC). In July 2009, a Fast-Fourier-Transform spectrometer (FFTS) has been added as backend to GROMOS. The new FFTS and the original filter bench (FB) measured parallel for over two years. In October 2011, the FB has been turned off and the FFTS is now used to continue the ozone time series. For a consolidated ozone time series in the frame of NDACC, the quality of the stratospheric ozone profiles obtained with the FFTS has to be assessed. The FFTS results from July 2009 to December 2011 are compared to ozone profiles retrieved by the FB. FFTS and $\mathrm{FB}$ of the GROMOS microwave radiometer agree within $5 \%$ above $20 \mathrm{hPa}$. A later harmonization of both time series will be realized by taking the FFTS as benchmark for the FB. Ozone profiles from the FFTS are also compared to coinciding lidar measurements from the Observatoire Haute Provence (OHP), France. For the time period studied a maximum mean difference (lidar - GROMOS FFTS) of $+3.8 \%$ at $3.1 \mathrm{hPa}$ and a minimum mean difference of $+1.4 \%$ at $8 \mathrm{hPa}$ is found. Further, intercomparisons with ozone profiles from other independent instruments are performed: satellite measurements include MIPAS onboard ENVISAT, SABER onboard TIMED, MLS onboard EOS Aura and ACE-FTS onboard SCISAT-1. Additionally, ozonesondes launched from Payerne, Switzerland, are used in the lower stratosphere. Mean relative differences of GROMOS FFTS and these independent instruments are less than $10 \%$ between 50 and $0.1 \mathrm{hPa}$.

\section{Introduction}

25 The stratospheric ozone layer protects life on Earth since ozone is the major absorber of (harmful) solar ultraviolet radiation. Changes to the ozone concentration alter the
AMTD

6, 6097-6146, 2013

Intercomparison of stratospheric ozone profiles

S. Studer et al.

\section{Title Page}

\section{Full Screen / Esc}

Printer-friendly Version

Interactive Discussion 
radiative balance and the dynamics of the Earth's atmosphere. Severe ozone depletion in form of the ozone hole was first recognized in 1983 over Antarctica (Chubachi, 1985; Farman et al., 1985). Stratospheric ozone depletion was attributed to anthropogenic emission of chlorofluorocarbons (CFCs) and in 1987, in the form of the Mon5 treal protocol, a global treaty was achieved to reduce the production of ozone depleting substances.

Today, $25 \mathrm{yr}$ after the Montreal protocol, prediction of the future ozone distribution remains a demanding task since the global ozone distribution depends on many factors such as the Brewer-Dobson circulation, the future evolution of man-made $\mathrm{CO}_{2}$ emis10 sion, abundances of other trace gases and polar stratospheric clouds (PSCs) (Reinsel et al., 2002; Randel and Wu, 2007; Harris et al., 2008; McLinden and Fioletov, 2011). Recently, Nair et al. (2013) analyzed the long-term evolution of ozone at the HauteProvence Observatory (OHP). They find ozone profile trends in the stratosphere are in the order of 0.3 and $0.1 \% \mathrm{yr}^{-1}$ for the $1997-2010$ period. Gebhardt et al. (2013) 15 report also on a moderately positive trend of around $0.5 \% \mathrm{yr}^{-1}$ between 40 and $45 \mathrm{~km}$ at northern midlatitudes.

Thus, continuous long-term ozone data sets are essential for the assessment of ozone recovery. Data sets of high quality and global coverage include the Total Ozone Mapping Spectrometer (TOMS) data record from NASA satellites (Antón et al., 2009) and the Solar Backscatter Ultraviolet (SBUV) data sets from NOAA weather satellites (Kramarova et al., 2013). To fulfill the requirements of accuracy, long-term stability and global coverage, the satellite network is supported by a ground station network. The Network for the Detection of Atmospheric Composition Change (NDACC) is a set of high quality, remote-sensing research stations for cross-validation and calibration of satellite missions.

Measurements of NDACC microwave radiometers are well suited for ozone monitoring in the stratosphere and lower mesosphere. They are operated nearly independent of weather conditions and measure day- and nighttime ozone profiles with the same
AMTD

$6,6097-6146,2013$

Intercomparison of stratospheric ozone profiles

S. Studer et al.

\section{Title Page}

Abstract Introduction Conclusions

Tables

References

Figures

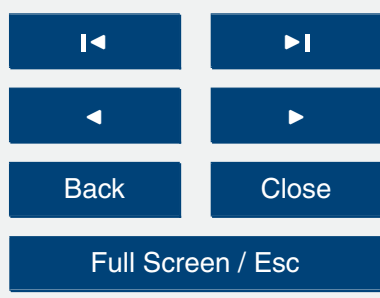

Printer-friendly Version

Interactive Discussion 
accuracy. Therefore, continuous time series of ozone volume mixing ratio profiles can be recorded.

At the University of Bern, Switzerland $\left(47.95^{\circ} \mathrm{N}, 7.44^{\circ} \mathrm{E}\right)$, the ozone radiometer GROMOS retrieves ozone profiles since November 1994 within the NDACC frame5 work. The backend in its original configuration is a filter bench (FB). A Fast-Fourier Transform spectrometer (FFTS) has been added in July 2009. In October 2011 the FB has been removed. Here, we show for the first time stratospheric ozone profiles as measured by the new FFTS for the period from July 2009 to December 2011. Data quality is addressed by comparing the FFTS results to ozone profiles obtained with the 10 FB of the GROMOS radiometer. To ensure a harmonization of the ozone time series in the future, the FB and the FFTS have been measuring in parallel over the course of more than two years. We further compare the GROMOS results to other, independent instruments such as satellites, lidar and ozonesondes.

Section 2 describes the GROMOS instrument and the GROMOS data set used in this 15 comparison. All further data used for the comparison study are presented in Sect. 3. Methods for the intercomparison are given in Sect. 4. In Sect. 5, annual and seasonal mean profiles of all used data sets and mean differences of coincident profile pairs are compared. Section 6 shows the seasonal and intraseasonal behavior of the different ozone time series from July 2009 to December 2011. Possible seasonal effects are investigated by means of time series of mean relative differences.

\section{GROMOS}

\subsection{Instrument}

The GROund-based Millimeter-wave Ozone Spectrometer GROMOS is an ozone radiometer, situated at the University of Bern $\left(47.95^{\circ} \mathrm{N}, 7.44^{\circ} \mathrm{E}\right)$, Switzerland. GROMOS is operated indoors continuously since November 1994 in the framework of the Network for the Detection of Atmospheric Composition Change (NDACC). Its data set is

\section{AMTD}

$6,6097-6146,2013$

Intercomparison of stratospheric ozone profiles

S. Studer et al.

\section{Title Page}

Abstract Introduction

Conclusions

Tables

References

Figures

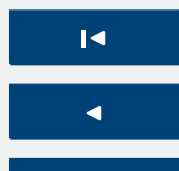

$>$ I

Back

Close

Full Screen / Esc

Printer-friendly Version

Interactive Discussion

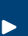

.

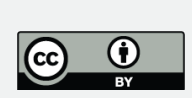


used for cross-validation of satellite experiments, studies of ozone-climate interactions and middle atmospheric dynamics, as well as for long-term monitoring of the ozone layer in the stratosphere (Peter and Kämpfer, 1995; Peter et al., 1996; Calisesi et al., 2001; Dumitru et al., 2006; Hocke et al., 2006, 2007, 2013; Steinbrecht et al., 2006, 5 2009; Flury et al., 2009; Studer et al., 2012).

GROMOS is a triple switched, total power radiometer. It measures the thermal microwave emission of the pressure-broadened ozone line at $142.175 \mathrm{GHz}$ and observes the middle atmosphere in north-east direction at an elevation angle of $40^{\circ}$. The detected radiation is reflected by a planar mirror and led through quasi optics, of which 10 the most important element is the Martin-Puplett interferometer (MPI). The optical path lengths of the MPI are adjusted for constructive interference at $142.175 \mathrm{GHz}$ and destructive interference at $149.575 \mathrm{GHz}$. After passing the MPI, the radiation is collected by a horn antenna. The signal is then mixed with the $145.875 \mathrm{GHz}$ wave of a local oscillator for down conversion to an intermediate frequency of $3.7 \mathrm{GHz}$.

15 A filterbench (FB) has been used for spectral analysis from November 1994 to October 2011. In July 2009, GROMOS has been upgraded and an Acqiris Fast-FourierTransfom spectrometer (FFTS), described in Müller et al. (2009), is used additionally as backend. The 45-channel filter bench had a bandwidth of $1.2 \mathrm{GHz}$ with a frequency resolution varying from $200 \mathrm{kHz}$ at the line center to $100 \mathrm{MHz}$ at the wings. The Acqiris FFTS covers a total bandwidth of $1 \mathrm{GHz}$ with 32768 channels, giving a frequency resolution of approximately $\Delta v=30 \mathrm{kHz}$. Calibration of the received intensity is performed by comparison with a hot load at $313 \mathrm{~K}$ and a liquid nitrogen cold load at $80 \mathrm{~K}$. The rotatable plane mirror is pointed to the radiation sources hot load, sky and cold load, alternating with a time step of about $8 \mathrm{~s}$. The receiver is operated in a stable ther25 mal environment at room temperature and the system temperature is roughly $2500 \mathrm{~K}$. GROMOS instrument specifications are summarized in Table 1.

A tropospheric correction for the tropospheric attenuation (mainly due to water vapor) is applied to the calibrated spectra by assuming an isothermal troposphere (Lobsiger et al., 1984; Lobsiger, 1987; Ingold et al., 1998). The transmission factor $e^{-\tau}$, where $\tau$

\section{AMTD}

$6,6097-6146,2013$

Intercomparison of stratospheric ozone profiles

S. Studer et al.

\section{Title Page}

Abstract

\section{Introduction}

Conclusions

Tables

References

Figures

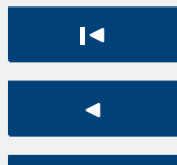

$\rightarrow 1$

Back

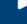

Close

\section{Full Screen / Esc}

Printer-friendly Version

Interactive Discussion

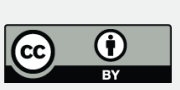


is the opacity, is estimated from the off-resonance emission at the wings of the ozone line. Tropospheric opacity is a spin-off of the tropospheric correction.

\subsection{Retrieval}

The pressure-broadened ozone line spectra can be inverted into ozone profiles from 5 approximately 20 to $70 \mathrm{~km}$. The retrieval of an ozone profile from the calibrated spectrum is known as the inverse problem. For the ozone profile retrieval of GROMOS, the Atmospheric Radiative Transfer Simulator ARTS (Eriksson et al., 2011) and the accompanying Matlab package Qpack (Eriksson et al., 2005) are used.

ARTS is a modular program simulating atmospheric radiative transfer. It calculates 10 an ozone line spectrum for a model atmosphere through radiative transfer calculations using an a priori ozone profile. Qpack takes advantage of ARTS and compares the modelled ozone spectrum with the observed ozone spectrum at $142 \mathrm{GHz}$. Using the optimal estimation method (OEM), as formulated by Rodgers (1976), Qpack derives the best estimate of the vertical profile of ozone volume mixing ratio with consideration of the uncertainties of the measured ozone spectrum and the a priori profile. OEM further provides a characterization and formal error analysis (Rodgers, 1990).

An estimate of the a priori contribution to the retrieval can be obtained by the area of the averaging kernels (AVK). For GROMOS, ozone volume mixing ratio (VMR) profiles are retrieved with less than $20 \%$ a priori contribution from 30 to $0.3 \mathrm{hPa}$ (altitudes from 20 about 25 to $57 \mathrm{~km}$ ).

The vertical resolution depends on altitude and can be deduced from the full width at half maximum (FWHM) of the AVK. In the case of GROMOS, the vertical resolution lies generally within 8-12 km in the stratosphere and increases with altitude to $20-25 \mathrm{~km}$ in the lower mesosphere. The averaging time required for a sufficient information content 25 from the measurement in the retrieved profile can be as low as a few minutes. In the standard retrieval, the time resolution is $30 \mathrm{~min}$, where the integrated spectra have a signal-to-noise ratio of approximately 30 (measurement noise is around $0.7 \mathrm{~K}$ and brightness temperature at the ozone line peak is around $20 \mathrm{~K}$ ).
AMTD

$6,6097-6146,2013$

Intercomparison of stratospheric ozone profiles

S. Studer et al.

\section{Title Page}

Abstract Introduction

Conclusions

Tables

References

Figures

14

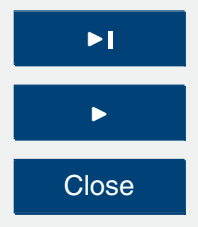

Back

Close

\section{Full Screen / Esc}

Printer-friendly Version

Interactive Discussion 
The a priori ozone profiles used in the GROMOS retrieval consists of monthly varying climatologies from ECMWF until available $(70 \mathrm{~km})$, extended by an Aura/MLS climatology (2004 to 2010) above. Figure 1 shows mean ozone profiles from GROMOS FFTS for January 2011 (blue) and July 2011 (magenta), together with the a priori profiles 5 (dashed lines) used in the retrieval for these two months. In the middle and right panel, one finds the mean AVK matrix for January 2011 and July 2011 respectively.

The line shape used in the retrieval is the representation of the Voigt line profile from Kuntz (1997). Spectroscopic parameters to calculate the ozone absorption coefficients were taken from the JPL catalogue (Pickett et al., 1998) and the HITRAN spectro10 scopic database (Rothman et al., 1998). For correction of a low bias in ozone found in the lower stratosphere, the line intensity and pressure broadening parameters have been reduced to $90 \%$ of the values given in the catalogues. The modified spectral line parameters are kept constant for the whole retrieval of the ozone time series. In difference to the $110 \mathrm{GHz}$ ozone line, the spectral parameters of the $142 \mathrm{GHz}$ ozone 15 line have not been measured in a laboratory yet. The spectroscopic modification may reduce a systematic error in the line parameters or it renders an unknown baseline perturbation of the ozone line spectrum.

The atmospheric temperature profiles are taken from 6 hourly ECMWF Operational Analysis data and are extended above $80 \mathrm{~km}$ by monthly mean temperatures of the CIRA-86 Atmosphere Model. The continuum is fitted by a straight line. No ozone profiles are retrieved for cases when the tropospheric opacity $\tau$ is larger than 1.6.

The total error includes systematic error and random error as well as the smoothing term. The systematic error originates from the tropospheric correction, calibration error due to systematic errors in the load temperatures, errors due to baseline features, 25 wrong spectral parameters, etc. The random error includes e.g. the thermal noise on the spectra. An error analysis has been performed by Peter (1997). The uncertainty resulting from the tropospheric correction was estimated by Ingold et al. (1998) and is smaller than $5 \%$. Thermal noise reduces with increasing integration time $t_{\text {int }}$ proportionally to $\frac{1}{t_{\text {int }}}$. With the standard integration time of $30 \mathrm{~min}$, the total error is in the order
AMTD

6, 6097-6146, 2013

Intercomparison of stratospheric ozone profiles

S. Studer et al.

\section{Title Page}

Abstract

Introduction

Conclusions

Tables

References

Figures

14 $\Delta$

4

Back

Close Full Screen / Esc

Printer-friendly Version

Interactive Discussion

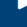 \\ (1)

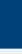 \\ (n)}


of $7 \%$ in the stratosphere $(35 \mathrm{~km} \pm 10 \mathrm{~km})$. The total error increases toward the lower and upper altitude limit: up to $20 \%$ at $20 \mathrm{~km}$ and up to $30 \%$ at $70 \mathrm{~km}$. The smoothing term is due to the limited altitude resolution.

Further information can be found in the microwave chapter of the data user guide of 5 the NORS project (Demonstration Network Of ground-based Remote Sensing Observations in support of the Copernicus Atmospheric Service (http://nors.aeronomie.be/).

\section{Correlative data}

\subsection{Lidar at the Haute-Provence Observatory (OHP)}

Ozone profiles have been measured since 1985 at the Observatoire de Haute10 Provence (OHP, $\left.44^{\circ} \mathrm{N}, 5.7^{\circ} \mathrm{E}\right)$ by the LIght Detection And Ranging (LIDAR) instrument. The lidar is an active remote sensing instrument: laser pulses of specific wavelengths are emitted into the atmosphere and interact with atmospheric particles and molecules. A small part of the radiation is reflected back by those objects and this backscattered radiation is collected by a telescope and transmitted to the detector. The ozone lidar

measurements at OHP are performed according to the Differential Absorption Lidar (DIAL) technique, which requires the emission of two laser wavelengths ( $308 \mathrm{~nm}$ and $355 \mathrm{~nm}$ ) with different ozone absorption cross sections. One wavelength is in the region of high absorption ( $308 \mathrm{~nm}$ ) and the other wavelength is less absorbed and considered as the reference wavelength $(355 \mathrm{~nm})$. Details of the derivation of the ozone number density from the OHP lidar measurements are described in Godin-Beekmann et al. (2003). Measurements are performed during night-time under clear sky conditions.

The typical integration time of a stratospheric ozone profile is $4 \mathrm{~h}$. The altitude range of measurements is between the tropopause and $45-50 \mathrm{~km}$. The vertical resolution ranges from $0.5 \mathrm{~km}$ at $20 \mathrm{~km}$ to about $2 \mathrm{~km}$ at $30 \mathrm{~km}$, and it increases to $4.5 \mathrm{~km}$ at $45 \mathrm{~km}$. The accuracy of the lidar ozone measurement depends partly on the accuracy of ozone absorption cross sections, which in turn depends on atmospheric tem-
AMTD

$6,6097-6146,2013$

Intercomparison of stratospheric ozone profiles

S. Studer et al.

\section{Title Page}

Abstract Introduction

Conclusions

Tables

References

Figures

14

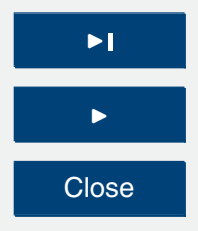

Back

Close

\section{Full Screen / Esc}

Printer-friendly Version

Interactive Discussion 
perature (Godin-Beekmann and Nair, 2012). As in Nair et al. (2011), a composite of temperature profiles, made from nearby radiosonde data (in the lower stratosphere), the National Center for Environmental Prediction (NCEP) (from 25 to $50 \mathrm{~km}$ ) and the COSPAR International Reference Atmosphere 1985 (CIRA-85) climatology (in the up5 per stratosphere) is used to compute the ozone cross section. These composites are also used for both the conversion of ozone number densities to the volume mixing ratio and geometric altitude to pressure vertical scale.

Typical accuracy estimates range from 3 to $7 \%$ from 15 to $40 \mathrm{~km}$. At $40-45 \mathrm{~km}$ and above, due to the rapid decrease in signal to noise ratio, the error bars increase and 10 significant bias reaching $10 \%$ may exist (Godin et al., 1999). Further details about the instrument can be found in Godin-Beekmann et al. (2003).

\subsection{Satellite instruments}

\subsubsection{MIPAS onboard ENVISAT}

The Michelson Interferometer for Passive Atmospheric Sounding (MIPAS) is a Fourier 15 transform spectrometer for the detection of limb emission spectra in the middle and upper atmosphere. It was launched onboard the sun-synchronous polar-orbiting European ENVIronmental SATellite (ENVISAT) in 2002 and was operational until April 2012. Details on the MIPAS instrument are described in Fischer et al. (2008).

In our comparison, we use the reduced spectral resolution ozone data product 20 V5R_O3_221 (V5R) provided by the Karlsruhe Institute of Technology (KIT) and Instituto de Astrofísica de Andalucía (IAA) (Takele Kenea et al., 2013). MIPAS ozone (version V4O_O3_202) was validated by Stiller et al. (2012). MIPAS ozone profiles show excellent agreement with Aura/MLS, lidar, ozonesondes and ACE-FTS. Except for a positive bias of around $10 \%$ at $37 \mathrm{~km}$, the percentage mean difference between V5R of MIPAS ozone profiles is in the process of being validated. First results of the comprehensive validation program are given in Laeng et al. (2012).

\section{AMTD}

6, 6097-6146, 2013

Intercomparison of stratospheric ozone profiles

S. Studer et al.

\section{Title Page}

Abstract Introduction

Conclusions

Tables

References

\section{Figures}

14 $\Delta$

4

Back

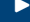

Close

\section{Full Screen / Esc}

Printer-friendly Version

Interactive Discussion 


\subsubsection{SABER onboard TIMED}

SABER (Sounding of the Atmosphere using Broadband Emission Radiometry) is one of four instruments on NASA's TIMED (Thermosphere lonosphere Mesosphere Energetics and Dynamics) mission. Its goal is to explore the mesosphere and lower ther-

5 mosphere globally (Russell et al., 1999; Remsberg et al., 2008). The TIMED satellite was launched in 2001 and is in a non-sun-synchronous orbit at $628 \mathrm{~km}$ mean altitude. Due to its drifting orbit, TIMED spans nearly all local times every 60 days.

The data used in this publication comprise ozone profiles from version 1.07 retrieved from the infrared emission of the $9.6 \mu \mathrm{m}$ band of ozone. In their validation, Rong et al. 10 (2009) found a SABER positive bias in all regions other than the lower stratosphere. They note that biases in the stratosphere vary from 5 to $17 \%$ with the largest bias found in equatorial to middle latitudes and between 30 and $50 \mathrm{~km}$. However, TIMED/SABER is focused on the mesosphere/lower thermosphere region where it already provided a large number of scientific discoveries.

\subsubsection{MLS onboard Aura}

The Earth Observing System (EOS) Microwave Limb Sounder (MLS) is a millimeterwave radiometer onboard the Aura satellite. Aura is in a near-polar orbit at an altitude of $705 \mathrm{~km}$ and is part of NASA's A-train group. The Aura satellite was launched in 2004. Among other constituents it observes the ozone rotational emission near $240 \mathrm{GHz}$. Due 20 to its sun-synchronous near-polar orbit, there are two overpasses per day for a given geographic location. For this comparison, ozone profiles from version 2.2 are used. Details about the Aura mission can be found in Waters et al. (2006) and Schoeberl et al. (2006) and the ozone measurements from version 2.2 have been validated by Jiang et al. (2007) and Froidevaux et al. (2008).

Jiang et al. (2007) note that in their comparison MLS ozone has a bias within $7 \%$ in the middle stratosphere compared to ozonesonde measurements. Their comparison to three sets of lidar measurements show agreement within about $5 \%$ in the stratosphere.
AMTD

$6,6097-6146,2013$

Intercomparison of stratospheric ozone profiles

S. Studer et al.

\section{Title Page}

Abstract Introduction

Conclusions

Tables References Figures

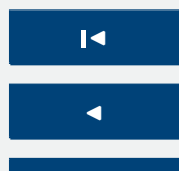

Back

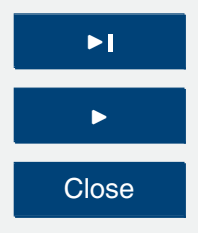

Full Screen / Esc

Printer-friendly Version

Interactive Discussion 
Hocke et al. (2006) compared ozone profiles of Aura/MLS and SOMORA at Payerne (Switzerland) and found mean differences less then $10 \%$ at altitudes from 25 to $45 \mathrm{~km}$. SOMORA is a $142 \mathrm{GHz}$ microwave radiometer and its measurement technique and design are similar to the GROMOS radiometer at Bern. SOMORA is operated by Me5 teoSwiss and also contributes to the NDACC network (Calisesi, 2003; Maillard Barras et al., 2009).

\subsubsection{ACE-FTS onboard SCISAT-1}

The Atmospheric Chemistry Experiment Fourier Transform Spectrometer (ACE-FTS) is the primary instrument on the Canadian satellite SCISAT-1 which was launched in 2003. ACE-FTS is a solar occultation instrument and SCISAT-1's near-polar orbit at an altitude of $650 \mathrm{~km}$ is optimized for measurement of ozone profiles at high latitudes. ACE-FTS measures in the infrared (IR) region of the spectrum. It covers $85 \%$ S- $85 \% \mathrm{~N}$ and the altitude range of the ozone retrievals extend from 10 to $95 \mathrm{~km}$. A mission overview is given by Bernath et al. (2005).

15 Validation of stratospheric ozone profiles from ACE-FTS version 2.2 was done by Dupuy et al. (2009). From 16 to $44 \mathrm{~km}$, they find mean relative differences within $1-8 \%$ when compared to satellite-borne, airborne, balloonborne and ground-based instruments. They note a persistent high bias of ACE-FTS in the mesosphere $(45-60 \mathrm{~km})$ with mean relative differences of up to $40 \%$. Ozone profiles from the new version 3.0 of the ACE-FTS retrieval software, used in this comparison, are in the process of being validated (Adams et al., 2012).

\subsection{ERA-Interim}

ERA-Interim reanalysis data is the latest global atmospheric reanalysis data set of the European Center for Medium-range Weather Forecast (ECMWF) and provides 6 hourly ozone profiles. It uses 60 vertical levels between the surface and $0.1 \mathrm{hPa}$. ERA-Interim is described in detail by Dee et al. (2011).
AMTD

$6,6097-6146,2013$

Intercomparison of stratospheric ozone profiles

S. Studer et al.

\section{Title Page}

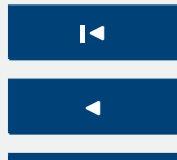

\section{Full Screen / Esc}

Printer-friendly Version

Interactive Discussion

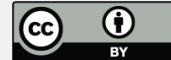


Dragani (2011) compared ERA-Interim ozone analyses with ozone profiles from a number of satellite instruments (SAGE, HALOE, UARS/MLS, Aura/MLS and POAM) for different latitudinal bands. They selected four pressure levels in the stratosphere (at $65,30,10$ and $5 \mathrm{hPa}$ ) for comparison: at $65 \mathrm{hPa}$, they find relative differences between

5 ERA-Interim with satellite measurements up to around $20 \%$. Between 10 and $5 \mathrm{hPa}$, the comparisons show good agreement and the relative differences are mostly within $\pm 5 \%$ at all latitudinal bands.

\subsection{Ozonesondes}

For the comparison, ozone profiles measured by ozonesondes launched from the Pay10 erne Aerological station $\left(46.80^{\circ} \mathrm{N}, 6.95^{\circ} \mathrm{E}\right)$ are taken. A profile is obtained up to the point where the ballon bursts, which is mostly at a pressure level around $10 \mathrm{hPa}$ (or an altitude of approximately $30 \mathrm{~km}$ ). Ozonesondes are launched three times a week on Monday, Wednesday and Friday noon (12:00 UT) and ozone is measured with an electrochemical concentration cell (ECC). A summary of the ozonesonde systems and 15 their performances can be found in Stübi et al. (2008) or Calisesi et al. (1998). The measurement uncertainty is about $5 \%$ in the stratosphere (below $10 \mathrm{hPa}$ ) and up to $25 \%$ between 10 and $3 \mathrm{hPa}$ (Smit et al., 2007).

\section{Method of intercomparison}

\subsection{Collocation and coincidence}

20 For the satellite-GROMOS intercomparison, the selected criterion for coincident profile pairs are differences less than $1.80^{\circ}$ in latitude, $10.50^{\circ}$ in longitude (corresponding to $\pm 200 \mathrm{~km}$ in latitude and $\pm 800 \mathrm{~km}$ in longitude) and $15 \mathrm{~min}$ in time with respect to the location and time of the GROMOS observation.

The Observatoire Haute Provence (OHP) lidar is situated $260 \mathrm{~km}$ from the location

of the GROMOS radiometer in Bern. The line-of-sight distance from Payerne to Bern is
AMTD

$6,6097-6146,2013$

Intercomparison of stratospheric ozone profiles

S. Studer et al.

\section{Title Page}

Abstract

Introduction

Conclusions

Tables

References

Figures

14

$\Delta$

4

Back

Close

Full Screen / Esc

Printer-friendly Version

Interactive Discussion
$>$ 
$42 \mathrm{~km}$ and Bleisch et al. (2011) showed through simulation with a trajectory model that most sondes launched in Payerne are driven towards Bern.

GROMOS provides ozone profiles with a time step of $30 \mathrm{~min}$. The percentage of missing ozone profiles due to high tropospheric opacity or instrument operation prob5 lems was $22 \%$ in the time interval from 2009 to 2011 . Thus, the probability is $88 \%$ to find for a satellite overpass above Bern a coincident ozone profile in the GROMOS database.

For the annual, seasonal and monthly mean profiles, all profiles that satisfied the spatial collocation criteria were averaged. For the mean difference profiles, additionally 10 to the collocation criteria, only GROMOS FFTS profiles that satisfied the following temporal coincidence were taken into account: $\Delta t_{\max }= \pm 15 \mathrm{~min}$. The number of collocated and coinciding pairs used in determining the average difference profiles of Sect. 5 is summarized in Table 2.

It has to be noted that in the (lower) mesosphere, the diurnal cycle in ozone has 15 a strong amplitude (up to $30 \%$ ) and one has to be careful of including day- and nighttime measurements for all instruments when averaging to mean profiles is performed. Day- and nighttime data were available for all instruments except for ozonesonde and lidar measurements.

Ozonesondes are always launched at 12:00 UT and only daytime profiles are avail20 able. In the case of comparison with lidar in Sect. 5, only coincident GROMOS profiles between 5 and 9 p.m. in winter and between 7 and 11 p.m. in summer have been taken into account, which amount to 308 profiles over the July 2009 to December 2011 period. For the annual, seasonal and monthly mean profiles in Sect. 6, the arithmetic averages of ENVISAT/MIPAS, TIMED/SABER, Aura/MLS, ERA-Interim and ozonesondes are taken. Only few ACE-FTS ozone profiles were found to satisfy the spatial and temporal selection critera between July 2009 and December 2011 (number of profiles: 14). Therefore, no averaging was possible and single profile values are shown in the monthly mean time series for ACE-FTS of Sect. 6 .
AMTD

$6,6097-6146,2013$

Intercomparison of stratospheric ozone profiles

S. Studer et al.

\section{Title Page}

Abstract Introduction Conclusions

Tables References Figures

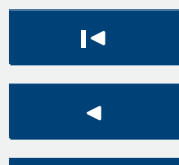
$\rightarrow 1$

\section{Full Screen / Esc}

Printer-friendly Version

Interactive Discussion 
The mean numbers of matching measurements per month available during the time period of July 2009 to December 2011 are: lidar $=11$ (only nighttime), GROMOS FB $=483$ (241 day- and 242 nighttime), MIPAS $=27$ (14 day- and 13 nighttime), $S A B E R=24$ (12 day- and 12 nighttime), MLS = 40 (20 day- and 20 nighttime),

\subsection{Averaging kernel smoothing}

To perform a comparison between two different instruments, one has to take into account the different vertical resolution and a priori data contribution. For this purpose, the vertical resolution of measurements from lidar, satellites and ozonesondes is reduced to the effective GROMOS altitude resolution. This is realized by convolving each profile with the corresponding averaging kernel matrix of GROMOS (Tsou et al., 1995). The convolved profile is expressed as:

$x_{\text {low }}=x_{\mathrm{a}}+\mathbf{A V K} \cdot\left(x_{\text {high }}-x_{\mathrm{a}}\right)$,

where $x_{\text {low }}$ is the convolved profile from lidar or satellite, $x_{\mathrm{a}}$ is the microwave a priori 15 profile, AVK is the matrix of GROMOS averaging kernel and $x_{\text {high }}$ is the measured lidar, satellite or ozonesonde profile interpolated to the GROMOS retrieval grid.

For the comparison, all profiles were further interpolated to a reference pressure grid $p$ as a function of $\log (p)$.

The mean relative difference profile $\Delta \mathrm{O}_{3, \text { rel }}$ was calculated in percent and with respect to GROMOS FFTS as

$\Delta \mathrm{O}_{3, \mathrm{rel}}=100 \cdot \frac{O_{3(\text { (nstr. })}-O_{3(\mathrm{FFTS})}}{O_{3(\mathrm{FFTS})}}$.

Intercomparison of stratospheric ozone profiles

S. Studer et al.

\section{Title Page}

Abstract Introduction

Conclusions References

Tables Figures
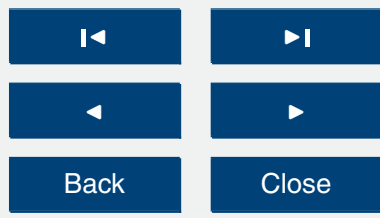

Full Screen / Esc

Printer-friendly Version

Interactive Discussion 


\section{Intercomparison results for annual and seasonal mean ozone profiles}

\subsection{Lidar}

AMTD

\subsubsection{Annual mean}

Annual mean ozone profiles from GROMOS FFTS and OHP lidar are presented in 5 Fig. 2. The averaged time period is July 2009 to June 2010 (left-hand side) and July 2010 to June 2011 (right-hand side). Two annual means are shown to see if there is a possible difference between the years. Volume mixing ratios are plotted against atmospheric pressure. Lidar profiles have been convolved with the averaging kernels of GROMOS (Eq. 1). The averaged ozone profiles of GROMOS FFTS are shown in magenta and lidar profiles are given by the red dashed-dotted curves. The lidar measures up to $\sim 2 \mathrm{hPa}$. Also given to the right of the mean profiles in Fig. 2 are the mean relative difference profiles $\Delta \mathrm{O}_{3 \text {,rel }}$ as defined by Eq. (2).

In both annual mean profiles, GROMOS FFTS and lidar show good agreement with GROMOS FFTS measuring slightly less ozone values compared to the lidar. The an15 nual mean relative differences $\Delta \mathrm{O}_{3 \text {,rel }}$ for both time periods are between +3 and $+8 \%$ in the 50 to $2 \mathrm{hPa}$ region (about 22 to $44 \mathrm{~km}$ ). Note that the two annual mean difference profiles show a similar structure and no large differences are evident between the two years.

\subsubsection{Seasonal mean}

20 Seasonal differences between GROMOS FFTS and lidar could have been smoothed out when calculating the annual mean profiles. Therefore, we investigate the existence of possible seasonal biases by looking at the mean seasonal profiles. Figures 3 and 4 show the mean profiles as well as the mean difference profiles from two years (2010 and 2011) for winter (December to February), spring (March to May), summer (June to August) and autumn (September to November). Clearly visible are the higher ozone

Intercomparison of stratospheric ozone profiles

S. Studer et al.

\section{Title Page}

Abstract Introduction

Conclusions

References

Tables Figures

14 - I

4

\section{Full Screen / Esc}

Printer-friendly Version

Interactive Discussion
$>$

ose

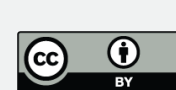


values of both instruments in summer compared to winter ( $8 \mathrm{ppm}$, respectively $6 \mathrm{ppm}$ ). Looking at the mean difference profiles of spring and autumn, we find them to be quite constant with altitude. While for summer, relative mean differences $\Delta \mathrm{O}_{3 \text {, rel }}$ are largest below $20 \mathrm{hPa}$, the largest difference in winter is found around ozone peak height at

$55 \mathrm{hPa}$. This larger difference in the middle stratosphere of winter can be due to the different measurement locations. The stratospheric ozone layer in winter is more disturbed than in summer due to high wave activity. In addition, strong horizontal gradients of ozone are present during winter when Bern and OHP are close to the polar vortex edge.

10 Overall, no seasonal biases are evident and relative mean differences $\Delta \mathrm{O}_{3, \text { rel }}$ between GROMOS FFTS and lidar are below $8 \%$.

\subsection{Satellites, ERA-interim and ozonesondes}

\subsubsection{Annual mean}

A comparison of annual mean profiles between GROMOS FFTS, GROMOS FB, satel15 lites, ozonesondes and ERA-Interim is shown in Fig. 5. Again, two annual averages are calculated: top panels shows the time period July 2009 to June 2010 and bottom panels show July 2010 to June 2011. The left panels give annual mean volume mixing ratio profiles. The mean relative difference profiles $\Delta \mathrm{O}_{3 \text {,rel }}$ (Eq. 2) are shown in the middle panels and the relative standard deviations can be found in the right panels. The data from satellite-borne instruments, ozonesonde and ERA-Interim profiles have been convolved with AVK from GROMOS FFTS to account for their higher vertical resolution (see Sect. 4.2). No AVK smoothing has been applied to the GROMOS FB profiles which have a vertical resolution comparable to GROMOS FFTS and similar a priori ozone profiles.

25 MIPAS is given by the orange lines, SABER in green dashed, GROMOS FB is given by the blue line while GROMOS FFTS is given in magenta. MLS is represented by the

AMTD

$6,6097-6146,2013$

Intercomparison of stratospheric ozone profiles

S. Studer et al.

\section{Title Page}

Abstract Introduction

Conclusions

Tables

References

Figures

14 $\Delta$

4

Back

\section{Full Screen / Esc}

Printer-friendly Version

Interactive Discussion
$>$

Close

(active Discussion

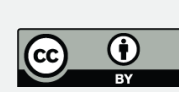


black line, ozonesondes in red dashed and finally ERA-Interim can be found in grey dashed.

The general agreement is within $10 \%$ between 50 and $0.1 \mathrm{hPa}$. Exceptions are SABER around $2 \mathrm{hPa}$ and ERA-Interim above $3 \mathrm{hPa}$. The large difference between

5 GROMOS FFTS and SABER can be explained by a previously reported, systematic high bias of $10-20 \%$ for SABER's ozone values from the middle stratosphere to the lower mesosphere (Rong et al., 2009).

ERA-Interim and GROMOS FFTS agree well up to $3 \mathrm{hPa}$ and the mean relative difference $\Delta \mathrm{O}_{3 \text {,rel }}$ is $\pm 5 \%$, while above ERA-Interim has about $10 \%$ less ozone. The 10 oscillatory nature of the relative standard deviations is a noticeable feature and visible in all data sets. Generally, GROMOS FFTS ozone profiles shows a slight negative bias of a few percent compared to the other data in the 50 to $0.1 \mathrm{hPa}$ region. The two annual means show a consistent picture and no large differences can be found between the annual means of July 2009-June 2010 and July 2010-June 2011.

\section{$15 \quad \mathbf{5 . 2 . 2}$ Seasonal mean}

To detect a possible seasonal bias, we look again at the seasonal mean profiles of the years 2010 and 2011 by summing the months of December to February (winter), the months of March to May (spring), the months of June to August (summer) and the months of September to November (autumn). The results can be found in Fig. 6a 20 (winter and spring) and Fig. 6b (summer and autumn). The mean ozone profiles are given in the left panels. The mean relative differences can be found in the middle panels and the right panels show the relative standard deviations of all data sets. The color code is the same as in the comparison of annual mean profiles of Fig. 5. For winter, we find indication for a double peak structure in all ozone profiles. The comparisons confirm the results of the previous Sect. 5.1. Namely, that ozone values from GROMOS FFTS are slightly lower than those from the external instruments. Looking at the mean relative differences of Fig. $6 a$ and $b$, we find a consistent picture with similar difference profiles for all seasons. An exception is ERA-Interim: in the winter upper stratosphere,

AMTD

$6,6097-6146,2013$

Intercomparison of stratospheric ozone profiles

S. Studer et al.

\section{Title Page}

Abstract Introduction

Conclusions

Tables

References

Figures

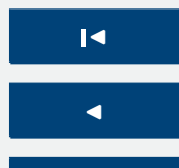

$\rightarrow 1$

Back

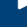

Close

Full Screen / Esc

Printer-friendly Version

Interactive Discussion
$>$

.


mean relative differences are up to $-25 \%$, while they are mostly within $\pm 10 \%$ for the other seasons. This strong winter deviation may be partly explained since accurate modelling of the stratospheric ERA-Interim ozone field at high latitudes is difficult during winter (Dragani, 2011).

$5 \quad$ Please note the larger standard deviations in the winter stratosphere (around $5 \%$ ) compared to summer (around $2 \%$ ). In winter, the stratosphere is more disturbed due to higher planetary wave activity than in summer, when the atmosphere is more stable. This can also be seen in the mean relative difference profile $\Delta \mathrm{O}_{3 \text {,rel }}$ of GROMOS FFTS and ozonesonde. We find that the agreement for summer is better (around $4 \%$ ) than for 10 winter (up to $12 \%$ ). As mentioned in Sect. 5.1.2, in winter, collocation might be more critical than in summer, since during winter months the polar vortex is often shifted toward midlatitudes and strong horizontal ozone gradients occur.

\section{Comparison of ozone time series}

\subsection{GROMOS and lidar}

15 Figure 7 displays the monthly mean time series of coinciding GROMOS FFTS (magenta line) and lidar (red dashed-dotted line) measurements for six pressure levels. Lidar profiles have been convolved with GROMOS FFTS averaging kernels. The data gap in November 2010 is due to missing lidar data during that month. GROMOS FFTS and lidar generally agree well at all pressure levels. Clearly visible is the strong annual variation in the stratosphere with maximal ozone values during summer months. The largest difference between GROMOS FFTS and lidar is found in the lower stratosphere at $31 \mathrm{hPa}$.

Monthly mean relative differences ((LIDAR-FFTS)/FFTS) are depicted in Fig. 8. Pressure levels are the same as in Fig. 7. Error bars are standard deviation of the averaged data. The mean relative difference is less than $10 \%$ for all pressure levels shown. The average mean difference for the whole time period July 2009-December 2011 is given
AMTD

$6,6097-6146,2013$

Intercomparison of stratospheric ozone profiles

S. Studer et al.

\section{Title Page}

Abstract Introduction

Conclusions

Tables

References

Figures

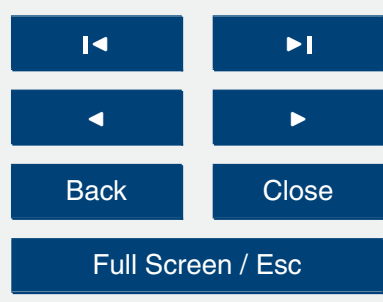

Printer-friendly Version

Interactive Discussion 
in the lower right corner for each pressure level. A maximum value of $+3.8 \%$ at $31 \mathrm{hPa}$ and a minimum value of $+1.4 \%$ at $7.6 \mathrm{hPa}$ is found.

\subsection{GROMOS, satellites and ERA-Interim}

The time series of GROMOS and ozone data from satellite-borne instruments as well 5 as ERA-Interim are shown in Fig. 9a to c. They display the monthly mean ozone values of collocated measurements on fixed pressure levels for the time period July 2009 to December 2011. Figure 9a shows lower mesospheric ozone, while Fig. 9b depicts middle stratospheric ozone and Fig. $9 \mathrm{c}$ the lower stratospheric ozone. Colors are the same as in the mean profiles of Sect. 5.2. MIPAS time series are only shown for altitudes at $1.1 \mathrm{hPa}$ and below. Since only a few ACE-FTS profiles have been found for the selection criteria applied, no averaging could be performed and single profile values for the given pressure levels are shown as grey squares.

The time series agree well at all altitudes. Some features are pointed out: (1) at $0.1 \mathrm{hPa}$, GROMOS FFTS values are larger than the other instruments during summer and smaller during winter, (2) ERA-Interim ozone clearly is underestimating ozone above $3.3 \mathrm{hPa}$ and has no annual cycle in contrast to all other instruments, (3) at $23 \mathrm{hPa}$, the largest differences can be found for GROMOS FFTS and GROMOS FB, while the satellite instruments cover the ozone VMR range in between.

Generally, GROMOS FFTS always measures at the lower edge of the range of ozone 20 values in all time series. This slight low bias of a few percent was already seen when looking at the mean profiles in Sect. 5. The bias of GROMOS FFTS in the stratosphere, Fig. 9b and c, appears to slightly improve with time and might be due to instrumental issues after adding the new FFTS backend in July 2009. Please also note the clear annual cycle, which shifts from winter maximum in the lower mesosphere to summer 25 maximum in the stratosphere. The strongest annual variation is observed at $10 \mathrm{hPa}$ (approximately at $35 \mathrm{~km}$ ). This findings agree with Dumitru et al. (2006).
AMTD

$6,6097-6146,2013$

Intercomparison of stratospheric ozone profiles

S. Studer et al.

\section{Title Page}

Abstract Introduction

Conclusions

Tables

References

\section{Figures}

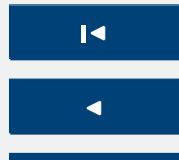

$\Delta$

Back

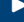

Close

\section{Full Screen / Esc}

Printer-friendly Version

Interactive Discussion 


\subsection{A closer look on GROMOS and Aura/MLS}

Time series of percent differences between collocated GROMOS FFTS and Aura/MLS ozone profiles are displayed in Fig. 10a to $\mathrm{c}$. The relative differences are calculated according to Eq. (2) and shown are the same pressure levels as used in Sect. 6.2.

5 The shaded grey area gives the relative mean standard deviation. The agreement is generally within $10 \%$ and improves with time.

In the stratosphere, the largest difference between GROMOS and Aura/MLS can be found in winter 2009/2010. A minor sudden stratospheric warming (SSW) occurred in December 2009, followed by major SSW event in January 2010 (Kuttippurath and

10 Nikulin, 2012). The larger variability associated with the disturbed winter stratosphere is also indicated by the larger standard deviation.

The mean relative difference for the whole time period is given in the lower right corners at each pressure level. The maximum is found at $0.6 \mathrm{hPa}$ with a mean difference of $+6.9 \%$, while the minimum is found around at $17.6 \mathrm{hPa}$ (around ozone volume mixing 15 ratio peak height) with a value of $+3.2 \%$.

A scatter plot of coincident ozone measurements of Aura/MLS and GROMOS FFTS for fixed pressure levels is given in Fig. 11. The black dashed-dotted line indicates 1-1, representing ideal agreement. The magenta line is the best fit straight line. The lines agree well for for pressure levels from 30.8 to $0.6 \mathrm{hPa}$. The correlation coefficients are given in the lower right corner for each pressure level. Good correlation is found for all altitudes. A maximum correlation of $R=0.95$ is found at $10 \mathrm{hPa}$. At $0.1 \mathrm{hPa}$, the correlation is minimal with $R=0.64$.

\subsection{Dynamics in the stratosphere}

Daily mean time series of ozone between 100 and $0.1 \mathrm{hPa}$ and from July 2009 to
FB, and collocated MLS, MIPAS, SABER and ERA-Interim reanalysis. No smoothing with GROMOS AVK has been applied to the satellite and ERA-Interim ozone profiles.
AMTD

$6,6097-6146,2013$

Intercomparison of stratospheric ozone profiles

S. Studer et al.

\section{Title Page}

\section{Full Screen / Esc}

Printer-friendly Version

Interactive Discussion 
The annual cycle can be clearly seen in all ozone data sets with stratospheric ozone values around $8 \mathrm{ppm}$ (red) in summer and around $6 \mathrm{ppm}$ (yellow) in winter. Similar structures in ozone variability are found in all time series, particularly when one looks at the winter periods of $2009 / 2010$ and $2010 / 2011$. The winter stratosphere is strongly 5 disturbed since wave activity is larger in winter than in summer (Tsuda et al., 2000; Alexander and Shepherd, 2010). All ozone time series show strong decrease and increase of ozone values over the course of a few weeks and exhibit signatures of atmospheric waves. These wave-like perturbation in ozone occur simultaneously and with similar amplitudes in all six time series. A major sudden stratospheric warming (SSW) 10 occurred in the Northern Hemisphere in January 2010 and led to a depletion of ozone. More details on the ozone distribution during SSW events can be found e.g. in Flury et al. (2009), Scheiben et al. (2012) and Goncharenko et al. (2012)

\section{Conclusions}

The GROund-based Millimeter-wave Ozone Spectrometer GROMOS is a $142 \mathrm{GHz}$ 15 Transform spectrometer (FFTS). To assess the quality of the ozone profiles retrieved from the high-resolution ozone line spectra of the FFTS, we compare ozone profiles from the FFTS with results from the original filter bench (FB) backend. The time period studied is July 2009 to December 2011.

20 Further, an intercomparison for the same time period is carried out by using other, independent data sets. These include collocated satellite data (MIPAS/ENVISAT, MLS/Aura, SABER/TIMED, ACE-FTS/SCISAT-1), lidar measurements from the Observatoire Haute Provence (OHP), ozonesondes profiles from Payerne and the ERAInterim ozone data product.

25 We find that GROMOS FFTS and GROMOS FB ozone profiles agree within $5 \%$ between 20 and $0.1 \mathrm{hPa}$. A homogenization between the GROMOS FB and GROMOS FFTS time series will be realized by taking the FFTS as benchmark for the FB. The
AMTD

$6,6097-6146,2013$

Intercomparison of stratospheric ozone profiles

S. Studer et al.

\section{Title Page}

Abstract Introduction

Conclusions

Tables

References

Figures

14

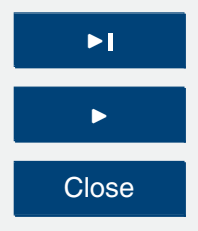

Back

Close 
mean difference between external instruments (satellite and lidar) and GROMOS FFTS was found to be within $10 \%$ for the 50 to $0.1 \mathrm{hPa}$ region. Over the whole time period July 2009 to December 2011, the average mean difference between GROMOS FFTS and lidar was maximal with $+3.8 \%$ at $31 \mathrm{hPa}$ and minimal with $+1.4 \%$ at $7.6 \mathrm{hPa}$. A closer 5 look at the time series from GROMOS FFTS and Aura/MLS show very good correlation on all pressure levels. Correlation coefficients range from $R=0.64$ at $0.1 \mathrm{hPa}$ (lowest correlation) to $R=0.95$ at $10 \mathrm{hPa}$ (highest correlation). The overall agreement between GROMOS FFTS and Aura/MLS is within $5 \%$ in the stratosphere.

GROMOS is thus well suited to provide local information about ozone changes on 10 intraseasonal and seasonal time scales. Due to the high time resolution of $30 \mathrm{~min}$, the data set of GROMOS enables us to study short-term ozone variations in the atmosphere such as e.g. the diurnal cycle in stratospheric ozone. After merging GROMOS FB and FFTS, we will be able to address changes in the ozone distribution above Switzerland over nearly two decades.

15 Acknowledgements. Simone Studer is funded by the Swiss National Science Foundation SNF under grant no. 200020-134613. The work was further supported by the EU project NORS (FP7-SPACE-2011-284421) and the International Space Science Institute (http://www.issibern. $\mathrm{ch} /$ teams/ozonetrend/). We thank the MLS- and SABER-team for the ozone data used in this study which was retrieved from the NASA Goddard Space Flight Center, the MIPAS-team 20 from Karlsruhe Institute of Technology (KIT) for provision of MIPAS ozone data. The ACEFTS/SCISAT-1 ozone profiles are mainly supported by the Canadian Space Agency and the Natural Sciences and Engineering Research Council of Canada. The author would further like to thank MeteoSwiss for providing us with ozonesonde data from Payerne.
AMTD

$6,6097-6146,2013$

Intercomparison of stratospheric ozone profiles

S. Studer et al.

\section{Title Page}

Abstract Introduction

Conclusions References

Tables Figures

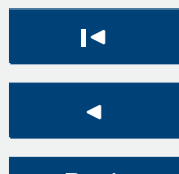

$\rightarrow 1$

Back

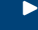

Close

Full Screen / Esc

Printer-friendly Version

Interactive Discussion 


\section{References}

Adams, C., Strong, K., Batchelor, R. L., Bernath, P. F., Brohede, S., Boone, C., Degenstein, D., Daffer, W. H., Drummond, J. R., Fogal, P. F., Farahani, E., Fayt, C., Fraser, A., Goutail, F., Hendrick, F., Kolonjari, F., Lindenmaier, R., Manney, G., McElroy, C. T., McLinden, C. A., Mendonca, J., Park, J.-H., Pavlovic, B., Pazmino, A., Roth, C., Savastiouk, V., Walker, K. A., Weaver, D., and Zhao, X.: Validation of ACE and OSIRIS ozone and $\mathrm{NO}_{2}$ measurements using ground-based instruments at $80^{\circ} \mathrm{N}$, Atmos. Meas. Tech., 5, 927-953, doi:10.5194/amt5-927-2012, 2012. 6107

Alexander, S. P. and Shepherd, M. G.: Planetary wave activity in the polar lower stratosphere, Atmos. Chem. Phys., 10, 707-718, doi:10.5194/acp-10-707-2010, 2010. 6117

Antón, M., López, M., Vilaplana, J. M., Kroon, M., McPeters, R., Bañón, M., and Serrano, A.: Validation of OMI-TOMS and OMI-DOAS total ozone column using five Brewer spectroradiometers at the Iberian peninsula, J. Geophys. Res.-Atmos., 114, D14307, doi:10.1029/2009JD012003, 2009. 6099

15 Bernath, P. F., McElroy, C. T., Abrams, M. C., Boone, C. D., Butler, M., Camy-Peyret, C., Carleer, M., Clerbaux, C., Coheur, P.-F., Colin, R., DeCola, P., DeMaziBernath, P. F., McElroy, C. T., Abrams, M. C., Boone, C. D., Butler, M., Camy-Peyret, C., Carleer, M., Clerbaux, C., Coheur, P.-F., Colin, R., DeCola, P., DeMaziere, M., Drummond, J. R., Dufour, D., Evans, W. F. J., Fast, H., Fussen, D., Gilbert, K., Jennings, D. E., Llewellyn, E. J., Lowe, R. P., Mahieu, E., McConnell, J. C., McHugh, M., McLeod, S. D., Michaud, R., Midwinter, C., Nassar, R., Nichitiu, F., Nowlan, C., Rinsland, C. P., Rochon, Y. J., Rowlands, N., Semeniuk, K., Simon, P., Skelton, R., Sloan, J. J., Soucy, M.-A., Strong, K., Tremblay, P., Turnbull, D., Walker, K. A., Walkty, I., Wardle, D. A., Wehrle, V., Zander, R., and Zou, J.: Atmospheric Chemistry Experiment (ACE): mission overview, Geophys. Res. Lett., 32, L15S01, doi:10.1029/2005GL022386, 2005. 6107

Bleisch, R., Kämpfer, N., and Haefele, A.: Retrieval of tropospheric water vapour by using spectra of a $22 \mathrm{GHz}$ radiometer, Atmos. Meas. Tech., 4, 1891-1903, doi:10.5194/amt-4-18912011, 2011. 6109

Calisesi, Y.: The Stratospheric Ozone MOnitoring RAdiometer SOMORA: NDSC Application Document, IAP Research report, University of Bern, Bern, Switzerland, 11, doi:10.1080/01431160902821890, 2003. 6107
AMTD

6, 6097-6146, 2013

Intercomparison of stratospheric ozone profiles

S. Studer et al.

\section{Title Page}

Abstract

Conclusions

References

Tables

Figures

14 $\Delta$

4

Back

\section{Full Screen / Esc}

Printer-friendly Version

Interactive Discussion 
Calisesi, Y., Peter, R., Kaempfer, N., and Stuebli, R.: Intercomparison of ozone profiles by radiosoundings over Payerne and microwave measurements in Bern: updated report, Research Report 98-9, Institut für angewandte Physik, Universität Bern, Bern, Switzerland, 1998. 6108

5 Calisesi, Y., Werli, H., and Kaempfer, N.: Midstratospheric ozone variability over Bern related to planetary wave activity during the winters 1994-1995 to 1998-1999, J. Geophys. Res., 106, 7903-7916, 2001. 6101

Chubachi, S.: A special ozone observation at syowa station, antarctica from February 1982 to January 1983, in: Atmospheric Ozone, edited by: Zerefos, C. and Ghazi, A., Springer Netherlands, 10.1007/978-94-009-5313-0_58, 285-289, 1985. 6099

Dee, D. P., Uppala, S. M., Simmons, A. J., Berrisford, P., Poli, P., Kobayashi, S., Andrae, U., Balmaseda, M. A., Balsamo, G., Bauer, P., Bechtold, P., Beljaars, A. C. M., van de Berg, L., Bidlot, J., Bormann, N., Delsol, C., Dragani, R., Fuentes, M., Geer, A. J., Haimberger, L., Healy, S. B., Hersbach, H., Hólm, E. V., Isaksen, L., Kållberg, P., Köhler, M., Matricardi, M., McNally, A. P., Monge-Sanz, B. M., Morcrette, J.-J., Park, B.-K., Peubey, C., de Rosnay, P., Tavolato, C., Thépaut, J.-N., and Vitart, F.: The ERA-Interim reanalysis: configuration and performance of the data assimilation system, Q. J. Roy. Meteorol. Soc., 137, 553-597, doi:10.1002/qj.828, 2011. 6107

Dragani, R.: On the quality of the ERA-Interim ozone reanalyses: comparison with satellite data, Q. J. Roy. Meteorol. Soc., 137, 1312-1326, doi:10.5194/amt-5-927-2012, 2011. 6107, 6114

Dumitru, M. C., Hocke, K., Kaempfer, N., and Calisesi, Y.: Comparison and validation studies related to ground-based microwave observations of ozone in the stratosphere and mesosphere, J. Atmos. Sol.-Terr. Phy., 68, 745-756, 2006. 6101, 6115
Dupuy, E., Walker, K. A., Kar, J., Boone, C. D., McElroy, C. T., Bernath, P. F., Drummond, J. R., Skelton, R., McLeod, S. D., Hughes, R. C., Nowlan, C. R., Dufour, D. G., Zou, J., Nichitiu, F., Strong, K., Baron, P., Bevilacqua, R. M., Blumenstock, T., Bodeker, G. E., Borsdorff, T., Bourassa, A. E., Bovensmann, H., Boyd, I. S., Bracher, A., Brogniez, C., Burrows, J. P., Catoire, V., Ceccherini, S., Chabrillat, S., Christensen, T., Coffey, M. T., Cortesi, U., Davies, J., De Clercq, C., Degenstein, D. A., De Mazière, M., Demoulin, P., Dodion, J., Firanski, B., Fischer, H., Forbes, G., Froidevaux, L., Fussen, D., Gerard, P., Godin-Beekmann, S., Goutail, F., Granville, J., Griffith, D., Haley, C. S., Hannigan, J. W., Höpfner, M., Jin, J. J., Jones, A., Jones, N. B., Jucks, K., Kagawa, A., Kasai, Y., Kerzenmacher, T. E., Kleinböhl, A., Kleko-

\section{AMTD}

6, 6097-6146, 2013

Intercomparison of stratospheric ozone profiles

S. Studer et al.

\section{Title Page}

Abstract Introduction

Conclusions References

Tables Figures
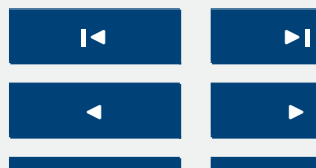

Back

\section{Full Screen / Esc}

Printer-friendly Version

Interactive Discussion 
ciuk, A. R., Kramer, I., Küllmann, H., Kuttippurath, J., Kyrölä, E., Lambert, J.-C., Livesey, N. J., Llewellyn, E. J., Lloyd, N. D., Mahieu, E., Manney, G. L., Marshall, B. T., McConnell, J. C., McCormick, M. P., McDermid, I. S., McHugh, M., McLinden, C. A., Mellqvist, J., Mizutani, K., Murayama, Y., Murtagh, D. P., Oelhaf, H., Parrish, A., Petelina, S. V., Piccolo, C., Pommereau, J.P., Randall, C. E., Robert, C., Roth, C., Schneider, M., Senten, C., Steck, T., Strandberg, A., Strawbridge, K. B., Sussmann, R., Swart, D. P. J., Tarasick, D. W., Taylor, J. R., Tétard, C., Thomason, L. W., Thompson, A. M., Tully, M. B., Urban, J., Vanhellemont, F., Vigouroux, C., von Clarmann, T., von der Gathen, P., von Savigny, C., Waters, J. W., Witte, J. C., Wolff, M., and Zawodny, J. M.: Validation of ozone measurements from the Atmospheric Chemistry Experiment (ACE), Atmos. Chem. Phys., 9, 287-343, doi:10.5194/acp-9-287-2009, 2009. 6107

Eriksson, P., Jiménez, C., and Buehler, S. A.: Qpack, a general tool for instrument simulation and retrieval work, J. Quant. Spectrosc. Ra., 91, 47-64, doi:10.1016/j.jqsrt.2004.05.050, 2005. 6102

Eriksson, P., Buehler, S. A., Davis, C. P., Emde, C., and Lemke, O.: ARTS, the atmospheric radiative transfer simulator, Version 2, J. Quant. Spectrosc. Ra., 112, 1551-1558, doi:10.1016/j.jqsit.2011.03.001, 2011. 6102

Farman, J. C., Gardiner, B. G., and Shanklin, J. D.: Large losses of total ozone in Antarctica reveal seasonal $\mathrm{ClO}_{x} / \mathrm{NO}_{x}$ interaction, Nature, 315, 207-210, doi:10.1038/315207a0, 1985. 6099

Fischer, H., Birk, M., Blom, C., Carli, B., Carlotti, M., von Clarmann, T., Delbouille, L., Dudhia, A., Ehhalt, D., Endemann, M., Flaud, J. M., Gessner, R., Kleinert, A., Koopman, R., Langen, J., López-Puertas, M., Mosner, P., Nett, H., Oelhaf, H., Perron, G., Remedios, J., Ridolfi, M., Stiller, G., and Zander, R.: MIPAS: an instrument for atmospheric and climate research, Atmos. Chem. Phys., 8, 2151-2188, doi:10.5194/acp-8-2151-2008, 2008. 6105

Flury, T., Hocke, K., Haefele, A., Kämpfer, N., and Lehmann, R.: Ozone depletion, water vapor increase, and PSC generation at midlatitudes by the 2008 major stratospheric warming, J. Geophys. Res., 114, D18302, doi:10.1029/2009JD011940, 2009. 6101, 6117

Froidevaux, L., Jiang, Y. B., Lambert, A., Livesey, N. J., Read, W. G., Waters, J. W., Browell, E. V., Hair, J. W., Avery, M. A., McGee, T. J., Twigg, L. W., Sumnicht, G. K., Jucks, K. W., Margitan, J. J., Sen, B., Stachnik, R. A., Toon, G. C., Bernath, P. F., Boone, C. D., Walker, K. A., Filipiak, M. J., Harwood, R. S., Fuller, R. A., Manney, G. L., Schwartz, M. J., Daffer, W. H., Drouin, B. J., Cofield, R. E., Cuddy, D. T., Jarnot, R. F., Knosp, B. W., Pe-

\section{AMTD}

6, 6097-6146, 2013

Intercomparison of stratospheric ozone profiles

S. Studer et al.

\section{Title Page}

Abstract Introduction

Conclusions References

Tables Figures

14

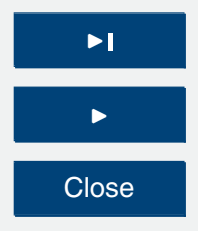

Back

Close 
run, V. S., Snyder, W. V., Stek, P. C., Thurstans, R. P., and Wagner, P. A.: Validation of Aura Microwave Limb Sounder stratospheric ozone measurements, J. Geophys. Res.-Atmos., 113, D15S20, doi:10.1029/2007JD008771, 2008. 6106

Gebhardt, C., Rozanov, A., Hommel, R., Weber, M., Bovensmann, H., Burrows, J. P., Degen5 stein, D., Froidevaux, L., and Thompson, A. M.: Stratospheric ozone trends and variability as seen by SCIAMACHY during the last decade, Atmos. Chem. Phys. Discuss., 13, 1126911313, doi:10.5194/acpd-13-11269-2013, 2013. 6099

Godin, S., Carswell, A. I., Donovan, D. P., Claude, H., Steinbrecht, W., McDermid, I. S., McGee, T. J., Gross, M. R., Nakane, H., Swart, D. P. J., Bergwerff, H. B., Uchino, O., von der Gathen, P., and Neuber, R.: Ozone Differential Absorption Lidar Algorithm Intercomparison, Appl. Optics, 38, 6225-6236, doi:10.1364/AO.38.006225, 1999. 6105

Godin-Beekmann, S. and Nair, P. J.: Sensitivity of stratospheric ozone lidar measurements to a change in ozone absorption cross-sections, J. Quant. Spectrosc. Ra., 113, 1317-1321, doi:10.1016/j.jqsrt.2012.03.002, 2012. 6105

15 Godin-Beekmann, S., Porteneuve, J., and Garnier, A.: Systematic DIAL lidar monitoring of the stratospheric ozone vertical distribution at Observatoire de Haute-Provence $\left(43.92^{\circ} \mathrm{N}\right.$, 5.71 ${ }^{\circ}$ E), J. Environ. Monitor., 5, 57-67, 2003. 6104, 6105

Goncharenko, L. P., Coster, A. J., Plumb, R. A., and Domeisen, D. I. V.: The potential role of stratospheric ozone in the stratosphere-ionosphere coupling during stratospheric warmings,

20 Geophys. Res. Lett., 39, L08101, doi:10.1029/2012GL051261, 2012. 6117

Harris, N. R. P., Kyrö, E., Staehelin, J., Brunner, D., Andersen, S.-B., Godin-Beekmann, S., Dhomse, S., Hadjinicolaou, P., Hansen, G., Isaksen, I., Jrrar, A., Karpetchko, A., Kivi, R., Knudsen, B., Krizan, P., Lastovicka, J., Maeder, J., Orsolini, Y., Pyle, J. A., Rex, M., Vanicek, K., Weber, M., Wohltmann, I., Zanis, P., and Zerefos, C.: Ozone trends at northern mid- and high latitudes - a European perspective, Ann. Geophys., 26, 1207-1220, doi:10.5194/angeo-26-1207-2008, 2008. 6099

Hocke, K., Kämpfer, N., Feist, D. G., Calisesi, Y., Jiang, J. H., and Chabrillat, S.: Temporal variance of lower mesospheric ozone over Switzerland during winter 2000/2001, Geophys. Res. Lett., 33, L09801, doi:10.1029/2005GL025496, 2006. 6101, 6107

so Hocke, K., Kämpfer, N., Ruffieux, D., Froidevaux, L., Parrish, A., Boyd, I., von Clarmann, T., Steck, T., Timofeyev, Y. M., Polyakov, A. V., and Kyrölä, E.: Comparison and synergy of stratospheric ozone measurements by satellite limb sounders and the ground-based microwave
AMTD

6, 6097-6146, 2013

Intercomparison of stratospheric ozone profiles

S. Studer et al.

\section{Title Page}

Abstract Introduction

Conclusions

Tables

References

Figures
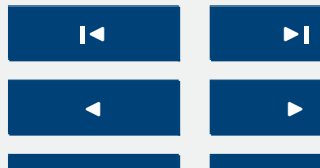

$\rightarrow 1$

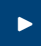

Back

Close

Full Screen / Esc

Printer-friendly Version

Interactive Discussion 
radiometer SOMORA, Atmos. Chem. Phys., 7, 4117-4131, doi:10.5194/acp-7-4117-2007, 2007. 6101

Hocke, K., Studer, S., Martius, O., Scheiben, D., and Kämpfer, N.: A 20-day period standing oscillation in the northern winter stratosphere, Ann. Geophys., 31, 755-764, 5 doi:10.5194/angeo-31-755-2013, 2013. 6101

Ingold, T., Peter, R., and Kämpfer, N.: Weighted mean tropospheric temperature and transmittance determination at milimeter-wave frequencies for ground-based application, Radio Sci., 33, 905-918, 1998. 6101, 6103

Jiang, Y. B., Froidevaux, L., Lambert, A., Livesey, N. J., Read, W. G., Waters, J. W., Bo10 jkov, B., Leblanc, T., McDermid, I. S., Godin-Beekmann, S., Filipiak, M. J., Harwood, R. S., Fuller, R. A., Daffer, W. H., Drouin, B. J., Cofield, R. E., Cuddy, D. T., Jarnot, R. F., Knosp, B. W., Perun, V. S., Schwartz, M. J., Snyder, W. V., Stek, P. C., Thurstans, R. P., Wagner, P. A., Allaart, M., Andersen, S. B., Bodeker, G., Calpini, B., Claude, H., Coetzee, G., Davies, J., De Backer, H., Dier, H., Fujiwara, M., Johnson, B., Kelder, H., Leme, N. P., König-Langlo, G., Kyro, E., Laneve, G., Fook, L. S., Merrill, J., Morris, G., Newchurch, M., Oltmans, S., Parrondos, M. C., Posny, F., Schmidlin, F., Skrivankova, P., Stubi, R., Tarasick, D., Thompson, A., Thouret, V., Viatte, P., Vömel, H., von Der Gathen, P., Yela, M., and Zablocki, G.: Validation of Aura Microwave Limb Sounder Ozone by ozonesonde and lidar measurements, J. Geophys. Res.-Atmos., 112, D24S34, doi:10.1029/2007JD008776, 2007. 6106

Kramarova, N. A., Frith, S. M., Bhartia, P. K., McPeters, R. D., Taylor, S. L., Fisher, B. L., Labow, G. J., and DeLand, M. T.: Validation of ozone monthly zonal mean profiles obtained from the Version 8.6 Solar Backscatter Ultraviolet algorithm, Atmos. Chem. Phys. Discuss., 13, 2549-2597, doi:10.5194/acpd-13-2549-2013, 2013. 6099

Kuntz, M.: A new implementation of the Humlicek algorithm for the calculation of the Voigt profile function, J. Quant. Spectrosc. Ra., 57, 819-824, doi:10.1016/S0022-4073(96)001628, 1997. 6103

Kuttippurath, J. and Nikulin, G.: A comparative study of the major sudden stratospheric warmings in the Arctic winters 2003/2004-2009/2010, Atmos. Chem. Phys., 12, 8115-8129, 30 doi:10.5194/acp-12-8115-2012, 2012. 6116

Laeng, A., Grabowski, U., Clarmann, T. V., Stiller, G., Kellmann, S., Kiefer, M., Linden, A., Lossow, S., Bathgate, T., Bernath, P., Boone, C. D., Clerbaux, C., Degenstein, D., Fritz, S., Froidevaux, L., Hervig, M., Hoppel, K., Lumpe, J., McHugh, M., Sano, T., Sofieva, V., Suzuki, M.,

AMTD

6, 6097-6146, 2013

Intercomparison of stratospheric ozone profiles

S. Studer et al.

\section{Title Page}

Abstract Introduction

Conclusions References

Tables Figures

14 DI

4

Back

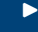
Close Full Screen / Esc

Printer-friendly Version

Interactive Discussion 
Tamminen, J., Urban, J., Walker, K., Weber, M., and Zawodny, J.: Validation of MIPAS IMK/IAA ozone profiles, in: Quadrennial Ozone Symposium, Toronto, 2012. 6105

Lobsiger, E.: Ground-based microwave radiometry to determine stratospheric and mesospheric ozone profiles, J. Atmos. Terr. Phys., 49, 493-501, 1987. 6101

5 Lobsiger, E., Künzi, K. F., and Dütsch, H. U.: Comparison of stratospheric ozone profiles retrieved from microwave-radiometer and Dobson-spectrometer data, J. Atmos. Terr. Phys., 46, 799-806, 1984. 6101

Maillard Barras, E., Ruffieux, D., and Hocke, K.: Stratospheric ozone profiles over Switzerland measured by SOMORA, ozonesonde and MLS/AURA satellite, Int. J. Remote Sens., 30, 4033-4041, 2009. 6107

McLinden, C. A. and Fioletov, V.: Quantifying stratospheric ozone trends: complications due to stratospheric cooling, Geophys. Res. Lett., 38, L03808, doi:10.1029/2010GL046012, 2011. 6099

Müller, S., Murk, A., Monstein, C., and Kämpfer, N.: Intercomparison of digital fast fourier trans15 form and acoustooptical spectrometers for microwave radiometry of the atmosphere, IEEE T. Geosci. Remote, 47, 2233-2239, doi:10.1109/TGRS.2009.2013695, 2009. 6101

Nair, P. J., Godin-Beekmann, S., Pazmiño, A., Hauchecorne, A., Ancellet, G., Petropavlovskikh, I., Flynn, L. E., and Froidevaux, L.: Coherence of long-term stratospheric ozone vertical distribution time series used for the study of ozone recovery at a northern mid-latitude station, Atmos. Chem. Phys., 11, 4957-4975, doi:10.5194/acp-11-4957-2011, 2011. 6105

Nair, P. J., Godin-Beekmann, S., Kuttippurath, J., Ancellet, G., Goutail, F., Pazmiño, A., Froidevaux, L., Zawodny, J. M., Evans, R. D., and Pastel, M.: Ozone trends derived from the total column and vertical profiles at a northern mid-latitude station, Atmos. Chem. Phys. Discuss., 13, 7081-7112, doi:10.5194/acpd-13-7081-2013, 2013. 6099

Peter, R.: The ground-based millimeter-wave ozone spectrometer-GROMOS, IAP Research Report, University of Bern, Bern, Switzerland, 13, 1997. 6103

Peter, R. and Kämpfer, N.: Short-term variations of mid-latitude ozone profiles during the winter 1994/95, in: Proc. Third Europ. Symp. on Polar O 3 Res., Air Pollution Res. Rep. No. 56 of the 30 EC, September 1995, Schliersee, Germany, 484-487, 1995. 6101

Peter, R., Caliseri, Y., and Kämpfer, N.: Variability of middle atmospheric ozone abundances derived from continuous ground-based millimeter wave measurements, in: Proceedings of the XVIII Quadrennial Ozone Symposium, 12-21 September 1996, L'Aquila, Italy, edited by:

\section{AMTD}

6, 6097-6146, 2013

Intercomparison of stratospheric ozone profiles

S. Studer et al.

\section{Title Page}

Abstract Introduction

Conclusions

Tables

References

Figures

14

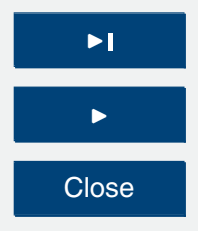

Back

\section{Full Screen / Esc}

Printer-friendly Version

Interactive Discussion 
Bojkov, R. D. and Visconti, G., Consorzio Parco Scientifico e Tecnologico d'Abruzzo, L'Aquila, Italy, Vol. 2, 559-562, 1998. 6101

Pickett, H. M., Poynter, R. L., Cohen, E. A., Delitsky, M. L., Pearson, J. C., and Müller, H. S. P.: Submillimeter, millimeter, and microwave spectral line catalog, J. Quant. Spectrosc. Ra., 60, 5 883-890, doi:10.1016/S0022-4073(98)00091-0, 1998. 6103

Randel, W. J. and Wu, F.: A stratospheric ozone profile data set for 1979-2005: Variability, trends, and comparison with column ozone data, J. Geophys. Res., 112, D06313, doi:10.1029/2006JD007339, 2007. 6099

Reinsel, G. C., Weatherhead, E. C., Tiao, G. C., Miller, A. J., Nagatani, R. M., Wuebbles, D. J., and Flynn, L. W.: On detection of turnaround and recovery in trend for ozone, J. Geophys. Res., 107, D10107, doi:10.1029/2001JD000500, 2002. 6099

Remsberg, E. E., Marshall, B. T., Garcia-Comas, M., Krueger, D., Lingenfelser, G. S., MartinTorres, J., Mlynczak, M. G., Russell, J. M., Smith, A. K., Zhao, Y., Brown, C., Gordley, L. L., Lopez-Gonzalez, M. J., Lopez-Puertas, M., She, C.-Y., Taylor, M. J., and Thompson, R. E.: Assessment of the quality of the Version 1.07 temperature-versus-pressure profiles of the middle atmosphere from TIMED/SABER, J. Geophys. Res.-Atmos., 113, D17101, doi:10.1029/2008JD010013, 2008. 6106

Rodgers, C. D.: Retrieval of atmospheric temperature and composition from remote measurements of thermal radiation, Rev. Geophys. Space Ge., 14, 609-624, 1976. 6102

20 Rodgers, C. D.: Characterization and error analysis of profiles retrieved from remote sounding measurements, J. Geophys. Res.-Atmos., 95, 5587-5595, doi:10.1029/JD095iD05p05587, 1990. 6102

Rong, P. P., Russell, J. M., Mlynczak, M. G., Remsberg, E. E., Marshall, B. T., Gordley, L. L., and López-Puertas, M.: Validation of thermosphere ionosphere mesosphere energetics and dynamics/sounding of the atmosphere using broadband emission radiometry (TIMED/SABER) v1.07 ozone at $9.6 \mu \mathrm{m}$ in altitude range $15-70 \mathrm{~km}$, J. Geophys. Res., 114, D04306, doi:10.1029/2008JD010073, 2009. 6106, 6113

Rothman, L., Rinsland, C., Goldman, A., Massie, S. T., and Edwards, D. P.: The HITRAN molecular spectroscopic database and HAWKS (HITRAN atmospheric workstation): 1996 edition,

$30 \quad$ J. Quant. Spectrosc. Ra., 60, 665-710, doi:10.1016/S0022-4073(98)00078-8, 1998. 6103

Russell, J. M., Mlynczak, M. G., Gordley, L. L., Tansock Jr., J. J., and Esplin, R. W.: Overview of the SABER experiment and preliminary calibration results, SPIE Proc. Ser., 3756, 277-288, doi:10.1117/12.366382, 1999. 6106
AMTD

6, 6097-6146, 2013

Intercomparison of stratospheric ozone profiles

S. Studer et al.

\section{Title Page}

Abstract Introduction

Conclusions

Tables

References

Figures

14

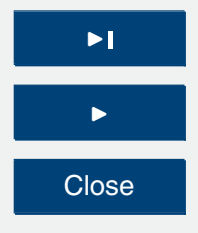

Back

Full Screen / Esc

Printer-friendly Version

Interactive Discussion 
Scheiben, D., Straub, C., Hocke, K., Forkman, P., and Kämpfer, N.: Observations of middle atmospheric $\mathrm{H}_{2} \mathrm{O}$ and $\mathrm{O}_{3}$ during the 2010 major sudden stratospheric warming by a network of microwave radiometers, Atmos. Chem. Phys., 12, 7753-7765, doi:10.5194/acp-12-77532012, 2012. 6117

5 Schoeberl, M., Douglass, A., Hilsenrath, E., Bhartia, P., Beer, R., Waters, J., Gunson, M., Froidevaux, L., Gille, J., Barnett, J., Levelt, P., and DeCola, P.: Overview of the EOS aura mission, IEEE T. Geosci. Remote, 44, 1066-1074, doi:10.1109/TGRS.2005.861950, 2006. 6106

Smit, H. G. J., Straeter, W., Johnson, B. J., Oltmans, S. J., Davies, J., Tarasick, D. W., Hoegger, B., Stubi, R., Schmidlin, F. J., Northam, T., Thompson, A. M., Witte, J. C., Boyd, I., and Posny, F.: Assessment of the performance of ECC-ozonesondes under quasi-flight conditions in the environmental simulation chamber: insights from the Juelich Ozone Sonde Intercomparison Experiment (JOSIE), J. Geophys. Res.-Atmos., 112, D19306, doi:10.1029/2006JD007308, 2007. 6108

Steinbrecht, W., Claude, H., Schönenborn, F., McDermid, I., Leblanc, T., Godin, S., Song, T., Swart, D., Meijer, Y., Bodeker, G., Connor, B., Kämpfer, N., Hocke, K., Calisesi, Y., Schneider, N., Noe, J., Parrish, A., Boyd, I., Brühl, C., Steil, B., Giorgetta, M., Manzini, E., Thomasson, L., Zawodny, J., McCormick, M., Russel III, J., Bhartia, P., Stolarski, R., and Hollandsworth-Frith, S.: Long-term evolution of upper stratospheric ozone at selected stations of the Network for the Detection of Stratospheric Change (NDSC), J. Geophys. Res., 111, D10308, doi:10.1029/2005JD006454, 2006. 6101

Steinbrecht, W., Claude, H., Schönenborn, F., McDermid, I., LeBlanc, T., Godin-Beekmann, S., Keckhut, P., Hauchecorne, A., van Gijsel, J., Swart, D., Bodeker, G., Parrish, A., Boyd, I., Kämpfer, N., Hocke, K., Stolarski, R., Frith, S., Thomason, L., Remsberg, E., von Savigny, C., Rozanov, A., and Burrows, J.: Ozone and temperature trends in the upper stratosphere at five stations of the Network for the Detection of Atmospheric Composition Change, Int. J. Remote Sens., 30, 3875-3886, 2009. 6101

Stiller, G. P., Kiefer, M., Eckert, E., von Clarmann, T., Kellmann, S., García-Comas, M., Funke, B., Leblanc, T., Fetzer, E., Froidevaux, L., Gomez, M., Hall, E., Hurst, D., Jordan, A., Kämpfer, N., Lambert, A., McDermid, I. S., McGee, T., Miloshevich, L., Nedoluha, G., Read, W., Schneider, M., Schwartz, M., Straub, C., Toon, G., Twigg, L. W., Walker, K., and Whiteman, D. N.: Validation of MIPAS IMK/IAA temperature, water vapor, and ozone
AMTD

6, 6097-6146, 2013

Intercomparison of

stratospheric ozone profiles

S. Studer et al.

\section{Title Page}

Abstract

Conclusions

References

Tables

Figures

14 $\Delta$

4

Back

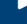

Close

\section{Full Screen / Esc}

Printer-friendly Version

Interactive Discussion 
profiles with MOHAVE-2009 campaign measurements, Atmos. Meas. Tech., 5, 289-320, doi:10.5194/amt-5-289-2012, 2012. 6105

Stübi, R., Levrat, G., Hoegger, B., Viatte, P., Staehelin, J., and Schmidlin, F. J.: In-flight comparison of Brewer-Mast and electrochemical concentration cell ozonesondes, J. Geophys.

$5 \quad$ Res.-Atmos., 113, 2156-2202, doi:10.1029/2007JD009091, 2008. 6108

Studer, S., Hocke, K., and Kämpfer, N.: Intraseasonal oscillations of stratospheric ozone above Switzerland, J. Atmos. Sol.-Terr. Phy., 74, 189-198, doi:10.1016/j.jastp.2011.10.020, 2012. 6101

Takele Kenea, S., Mengistu Tsidu, G., Blumenstock, T., Hase, F., von Clarmann, T., and Stiller, G. P.: Retrieval and satellite intercomparison of $\mathrm{O}_{3}$ measurements from ground-based FTIR Spectrometer at Equatorial Station: Addis Ababa, Ethiopia, Atmos. Meas. Tech., 6, 495-509, doi:10.5194/amt-6-495-2013, 2013. 6105

Tsou, J. J., Connor, B. J., Parrish, A., McDermid, I. S., and Chu, W. P.: Ground-based microwave monitoring of middle atmosphere ozone: comparison to lidar and stratospheric and Gas Experiment II satellite observations, J. Geophys. Res.-Atmos,, 100, 3005-3016, doi:10.1029/94JD02947, 1995. 6110

Tsuda, T., Nishida, M., Rocken, C., and Ware, R. H.: A global morphology of gravity wave activity in the stratosphere revealed by the GPS occultation data (GPS/MET), J. Geophys. Res.-Atmos., 105, 7257-7273, doi:10.1029/1999JD901005, 2000. 6117

Waters, J., Froidevaux, L., Harwood, R., Jarnot, R., Pickett, H., Read, W., Siegel, P., Cofield, R., Filipiak, M., Flower, D., Holden, J., Lau, G., Livesey, N., Manney, G., Pumphrey, H., Santee, M., Wu, D., Cuddy, D., Lay, R., Loo, M., Perun, V., Schwartz, M., Stek, P., Thurstans, R., Boyles, M., Chandra, K., Chavez, M., Chen, G., Chudasama, B., Dodge, R., Fuller, R., Girard, M., Jiang, J., Jiang, Y., Knosp, B., LaBelle, R., Lam, J., Lee, K., Miller, D., Oswald, J., Walch, M.: The Earth Observing System Microwave Limb Sounder (EOS MLS) on the Aura satellite, IEEE T. Geosci. Remote, 44, 1075-1092, 2006. 6106

AMTD

$6,6097-6146,2013$

Intercomparison of stratospheric ozone profiles

S. Studer et al.

\section{Title Page}

Abstract Introduction

Conclusions References

Tables Figures
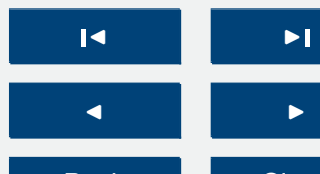

Back

Close

Full Screen / Esc

Printer-friendly Version

Interactive Discussion 


\section{AMTD}

6, 6097-6146, 2013

Intercomparison of stratospheric ozone profiles

Table 1. GROMOS instrument specifications.

\begin{tabular}{|c|c|}
\hline Location & Bern, Switzerland \\
\hline Direction of view & $46.95^{\circ} \mathrm{N}, 7.44^{\circ} \mathrm{E}, 577 \mathrm{~m}$ \\
\hline Elevation of antenna & $40^{\circ}$ \\
\hline Mode of operation & Total power \\
\hline Temperature of mixer & $294 \mathrm{~K}$ (uncooled, room temperature) \\
\hline System noise temperature & $2520 \mathrm{~K}$ \\
\hline Frequency of ozone line & $142.17504 \mathrm{GHz}$ \\
\hline Target species & $\mathrm{O}_{3}$ \\
\hline Auxiliary quantities & Opacity \\
\hline Altitude range of target species & $25-70 \mathrm{~km}$ \\
\hline Spectrometer & $\begin{array}{l}\text { 48-channel filterbench (FB, 1994-2011) } \\
\text { 32 768-channel FFT spectrometer (FFTS, } \\
\text { since 2009) }\end{array}$ \\
\hline Time resolution & $30 \mathrm{~min}(\mathrm{FFTS}), 60 \mathrm{~min}(\mathrm{FB})$ \\
\hline
\end{tabular}

S. Studer et al.

Title Page

Abstract

Introduction

Conclusions

References

Tables

Figures

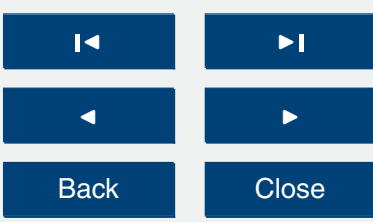

Full Screen / Esc

Printer-friendly Version

Interactive Discussion 


\section{AMTD}

$6,6097-6146,2013$

Intercomparison of stratospheric ozone profiles

S. Studer et al.

Table 2. Number of coincident measurement pairs between GROMOS FFTS and the comparison instruments.

\begin{tabular}{lrrrrrr}
\hline Instrument & Jul 2009-Jun 2010 & Jul 2010-Jun 2011 & Winter & Spring & Summer & Autumn \\
\hline Lidar & 114 & 115 & 38 & 53 & 70 & 70 \\
FB & 6073 & 6283 & 3268 & 3340 & 2522 & 3125 \\
MIPAS & 303 & 313 & 167 & 174 & 161 & 134 \\
SABER & 278 & 292 & 147 & 150 & 137 & 152 \\
MLS & 531 & 495 & 257 & 234 & 253 & 264 \\
O $_{3}$-Sonde & 134 & 137 & 65 & 69 & 62 & 67 \\
ERA-Interim & 1234 & 1104 & 626 & 640 & 622 & 633 \\
\hline
\end{tabular}

Title Page

Abstract

Introduction

Conclusions

References

Tables

Figures

14

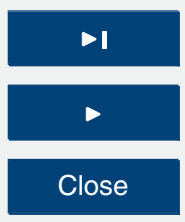

Back

Close

Full Screen / Esc

Printer-friendly Version

Interactive Discussion 

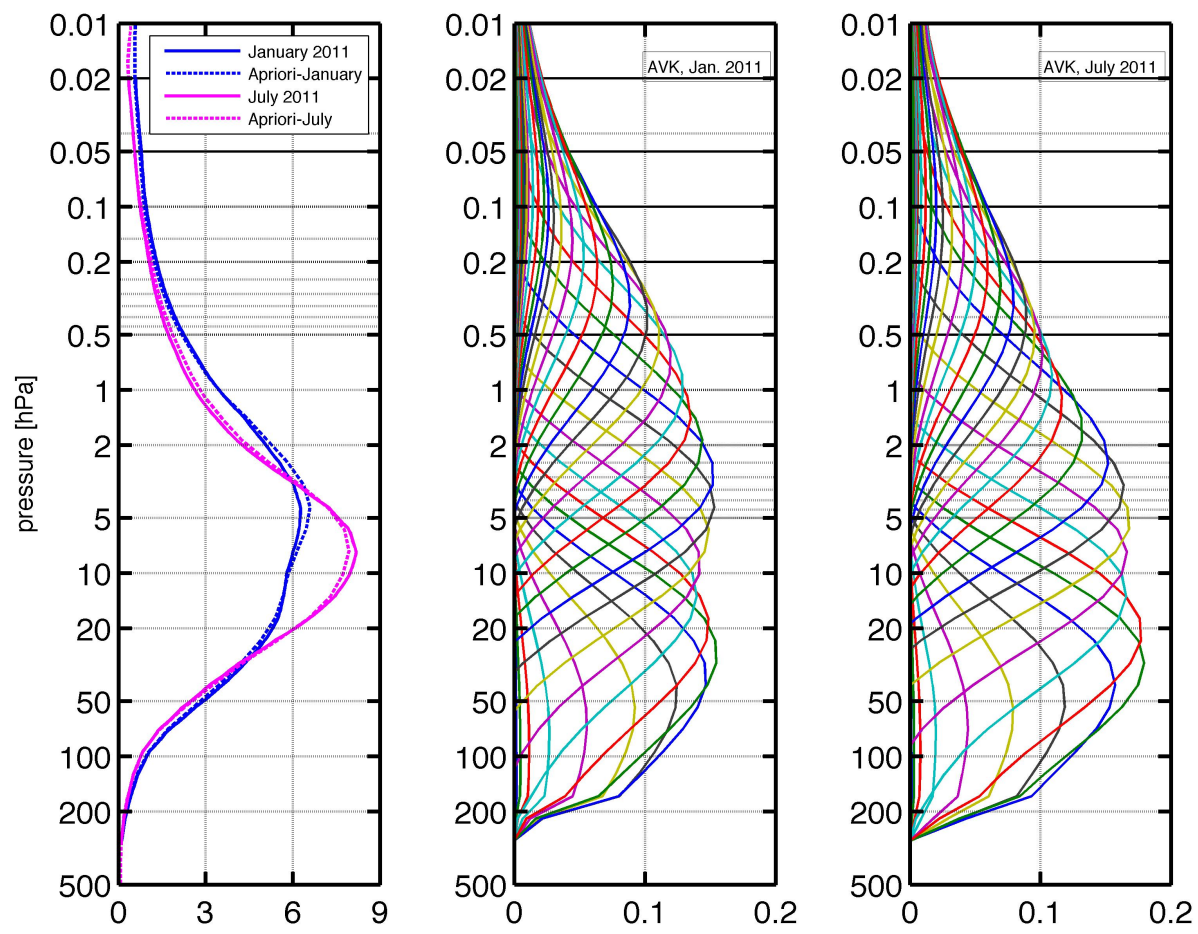

6, 6097-6146, 2013

\section{Intercomparison of stratospheric ozone profiles}

S. Studer et al.

\section{Title Page}

\section{Abstract}

Introduction

Conclusions

References

Tables

Figures
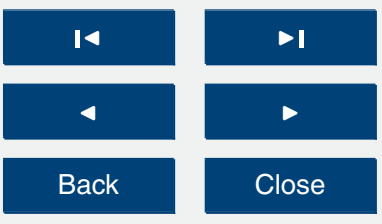

Full Screen / Esc

Fig. 1. Left panel: mean ozone profiles retrieved during January (blue curve) and July 2011 (magenta curve) with the GROMOS FFTS together with the a priori profiles. Middle and right panel: averaging kernel matrix obtained with the GROMOS FFTS forward model for January 2011 (middle panel) and July 2011 (right panel).

Interactive Discussion

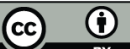



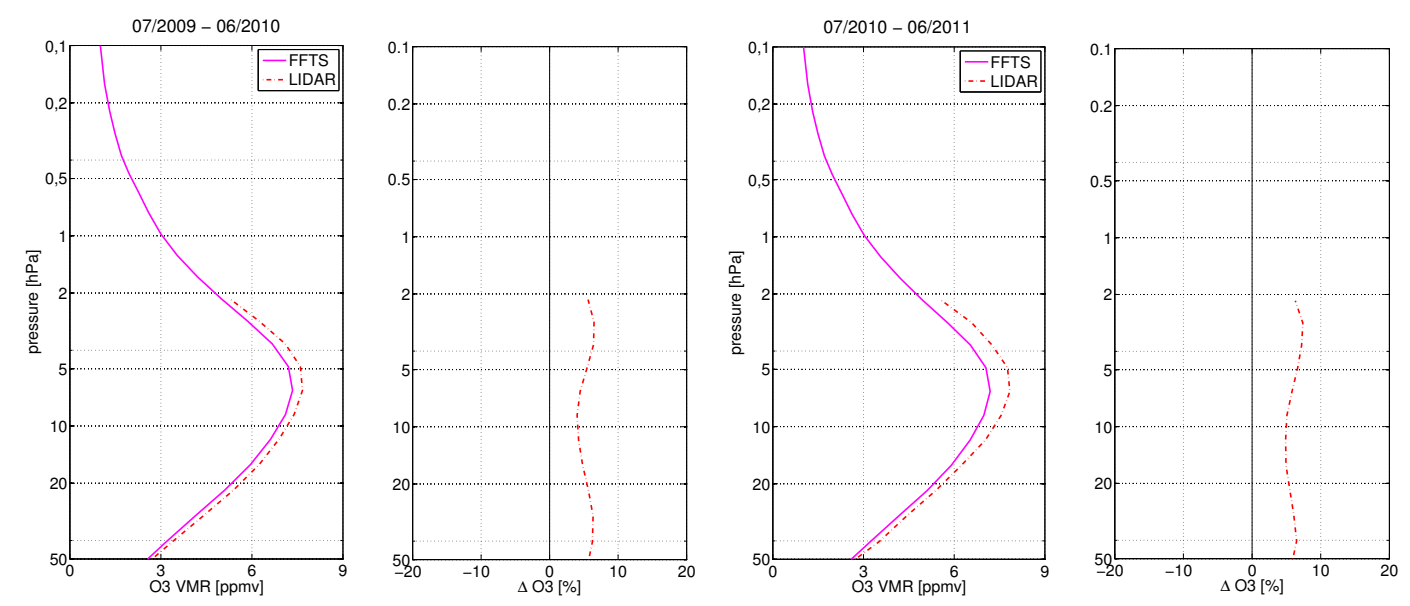

Fig. 2. Annual mean profiles from GROMOS FFTS (magenta) and LIDAR (red dashed) and relative difference profiles $\Delta \mathrm{O}_{3, \text { rel }}$ (for definition see Eq. 2). The time period to the left is for July 2009 to June 2010, while the one to the right is July 2010 to June 2011.

\section{AMTD}

$6,6097-6146,2013$

\section{Intercomparison of stratospheric ozone profiles}

S. Studer et al.

\section{Title Page}

Abstract

Introduction

Conclusions

References

Tables

Figures

14

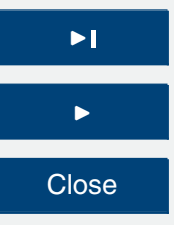

Back

Close

Full Screen / Esc

Printer-friendly Version

Interactive Discussion 

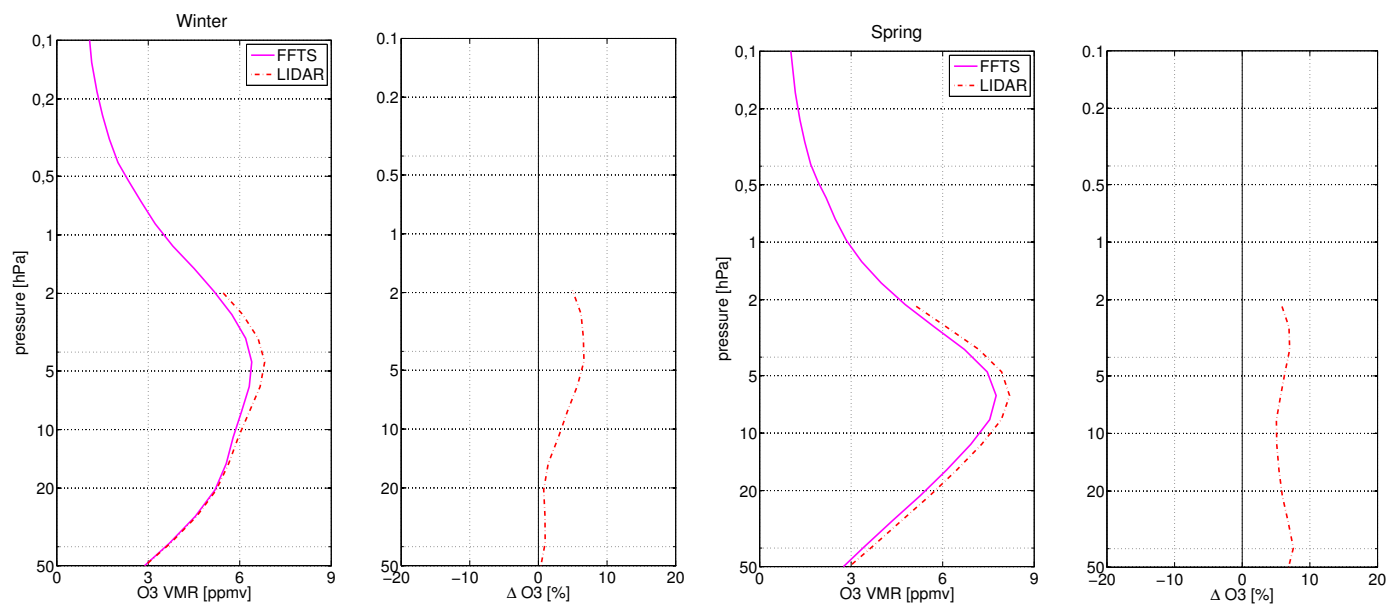

AMTD

$6,6097-6146,2013$

\section{Intercomparison of stratospheric ozone profiles}

S. Studer et al.

\section{Title Page}

Abstract

Introduction

Conclusions

References

Tables

Figures

Fig. 3. Seasonal mean and relative difference profiles from GROMOS FFTS (magenta) and LIDAR (red dashed) for winter (left panels) and spring (right panels).

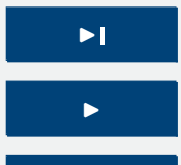

Back

Close

Full Screen / Esc

Printer-friendly Version

Interactive Discussion

(c) (1) 

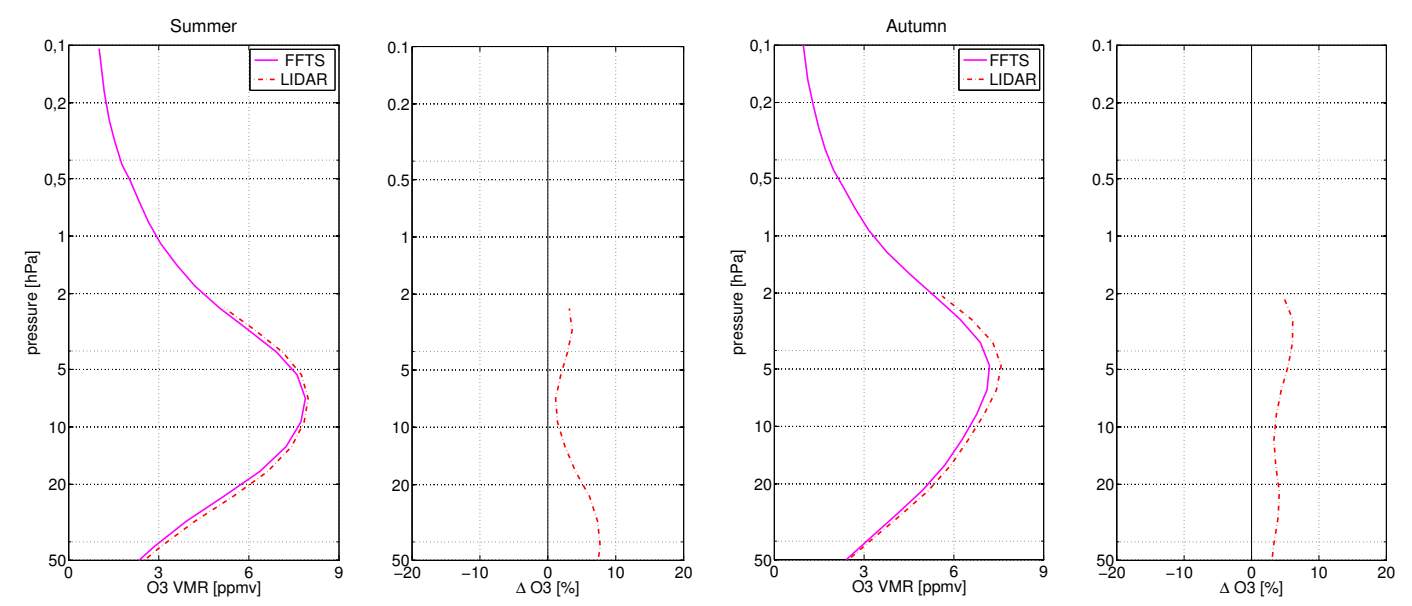

Fig. 4. Seasonal mean and relative difference profiles from GROMOS FFTS (magenta) and LIDAR (red dashed) for summer (left panels) and autumn (right panels).

\section{AMTD}

6, 6097-6146, 2013

\section{Intercomparison of stratospheric ozone profiles}

S. Studer et al.

\section{Title Page}

\section{Abstract}

Introduction

Conclusions

References

Tables

Figures

14

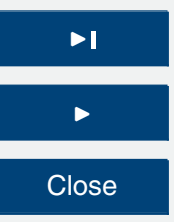

Back

Close

Full Screen / Esc

Printer-friendly Version

Interactive Discussion 

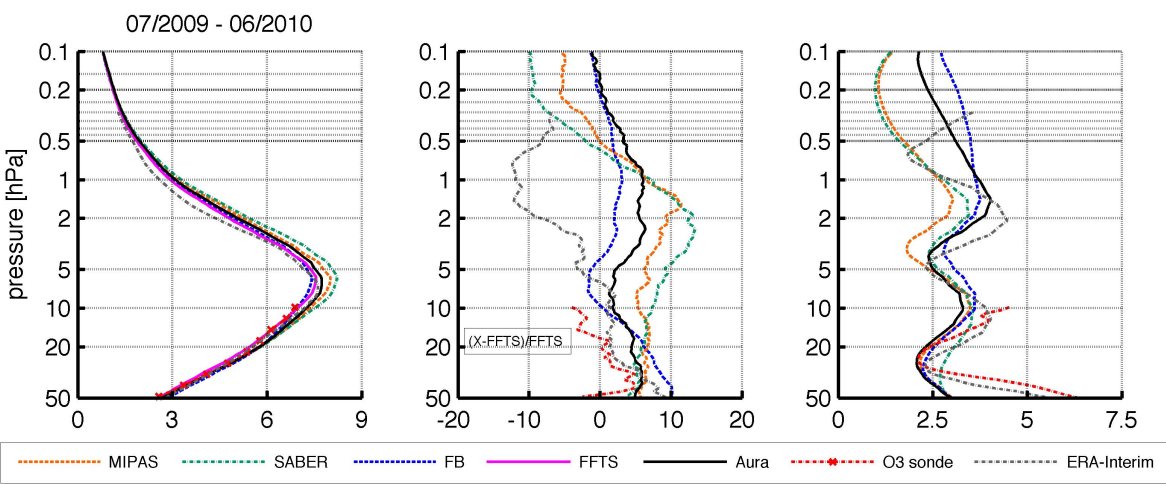

AMTD

$6,6097-6146,2013$
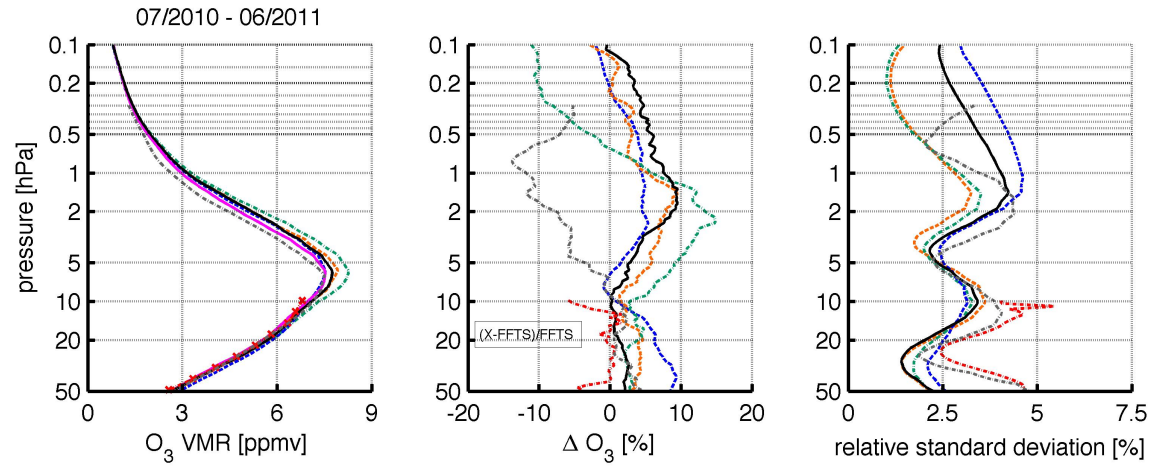

Title Page

Abstract

Introduction

Conclusions

References

Tables

Figures

Fig. 5. Annual mean profiles for July 2009 to June 2010 (upper panels) and July 2010 to June 2011 (lower panels). Left panels: mean profiles from GROMOS FB (blue), GROMOS FFTS (magenta), MIPAS (orange), SABER (green dashed), MLS (black), $\mathrm{O}_{3}$-sondes (red dashed) and ERA-Interim (grey dashed). Middle panels: mean relative difference profiles $\Delta \mathrm{O}_{3 \text {,rel }}$ between GROMOS FFTS and instrument as defined in Eq. (2) (color code as in mean profiles). Right panels: mean relative standard deviation of various instruments (color code as in mean profiles).

14

4

Back

Close

Full Screen / Esc

Printer-friendly Version

Interactive Discussion 

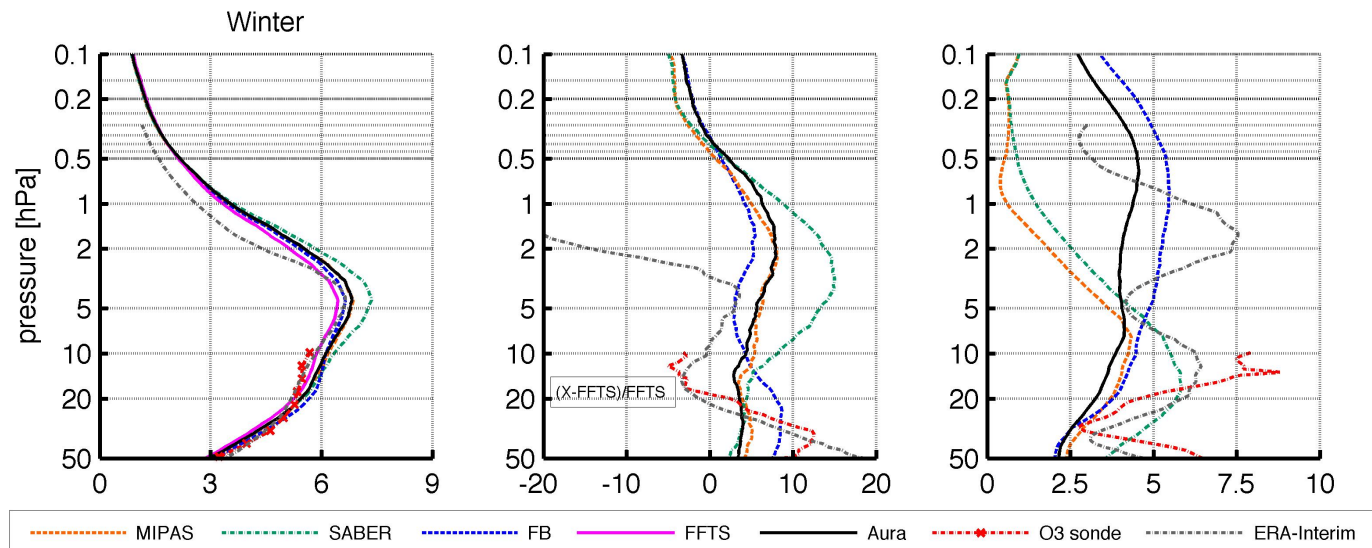

AMTD

6, 6097-6146, 2013
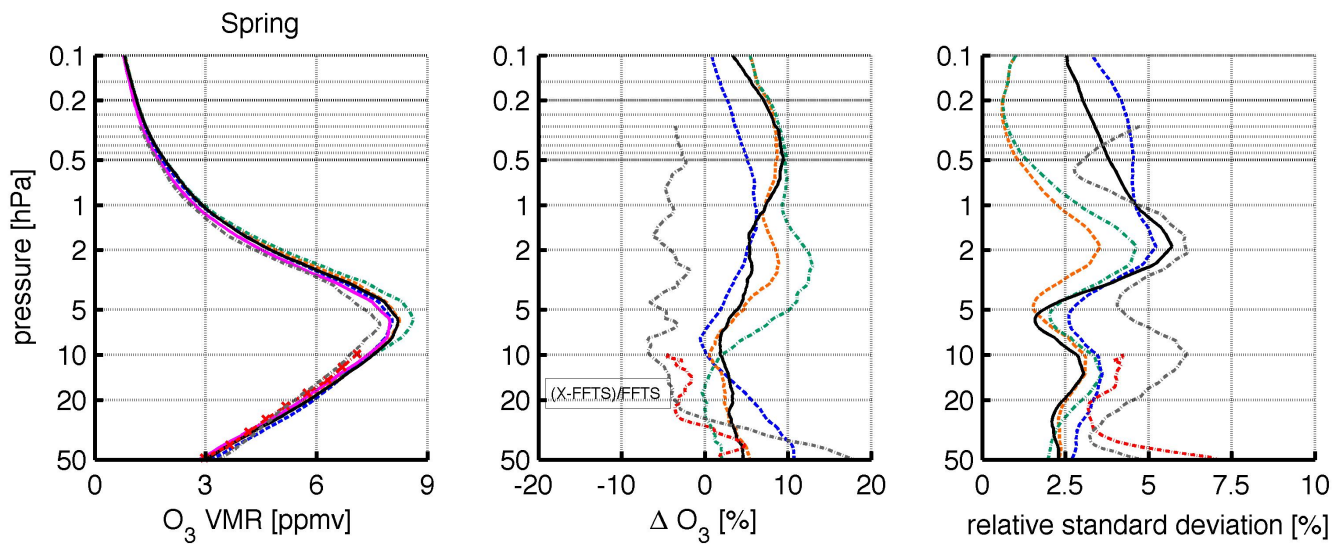

Intercomparison of stratospheric ozone profiles

S. Studer et al.

\section{Title Page}

Fig. 6a. Seasonal mean profiles: upper panels show winter (December to February), lower panels show spring (March to May). Left panels: mean profiles. Middle panels: mean relative differences. Right panels: mean relative standard deviation. Colors are as in Fig. 5.
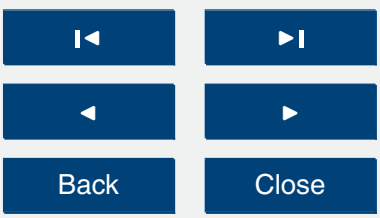

\section{Full Screen / Esc}

Printer-friendly Version

Interactive Discussion 

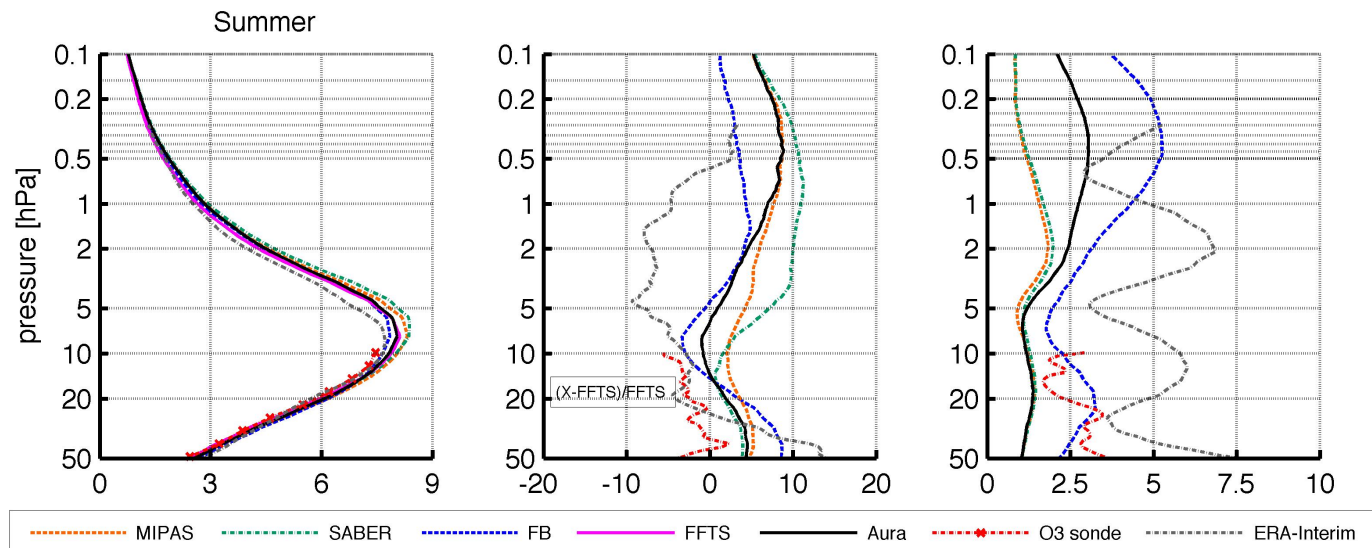

AMTD

6, 6097-6146, 2013
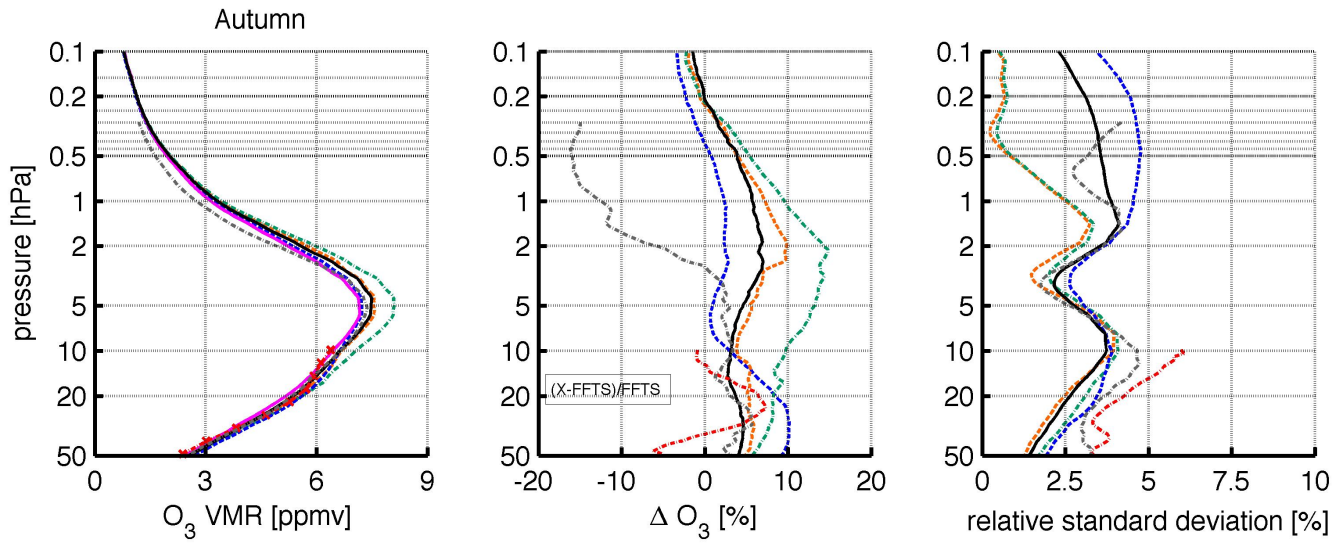

Intercomparison of stratospheric ozone profiles

S. Studer et al.

\section{Title Page}

Fig. 6b. Seasonal mean profiles: upper panels show summer (June to August), lower panels show autumn (September to November). Left panels: mean profiles. Middle panels: mean relative differences. Right panels: mean relative standard deviation. Colors are as in Fig. 5.

14

4

Back

\section{Full Screen / Esc}

Printer-friendly Version

Interactive Discussion 


\section{AMTD}

6, 6097-6146, 2013
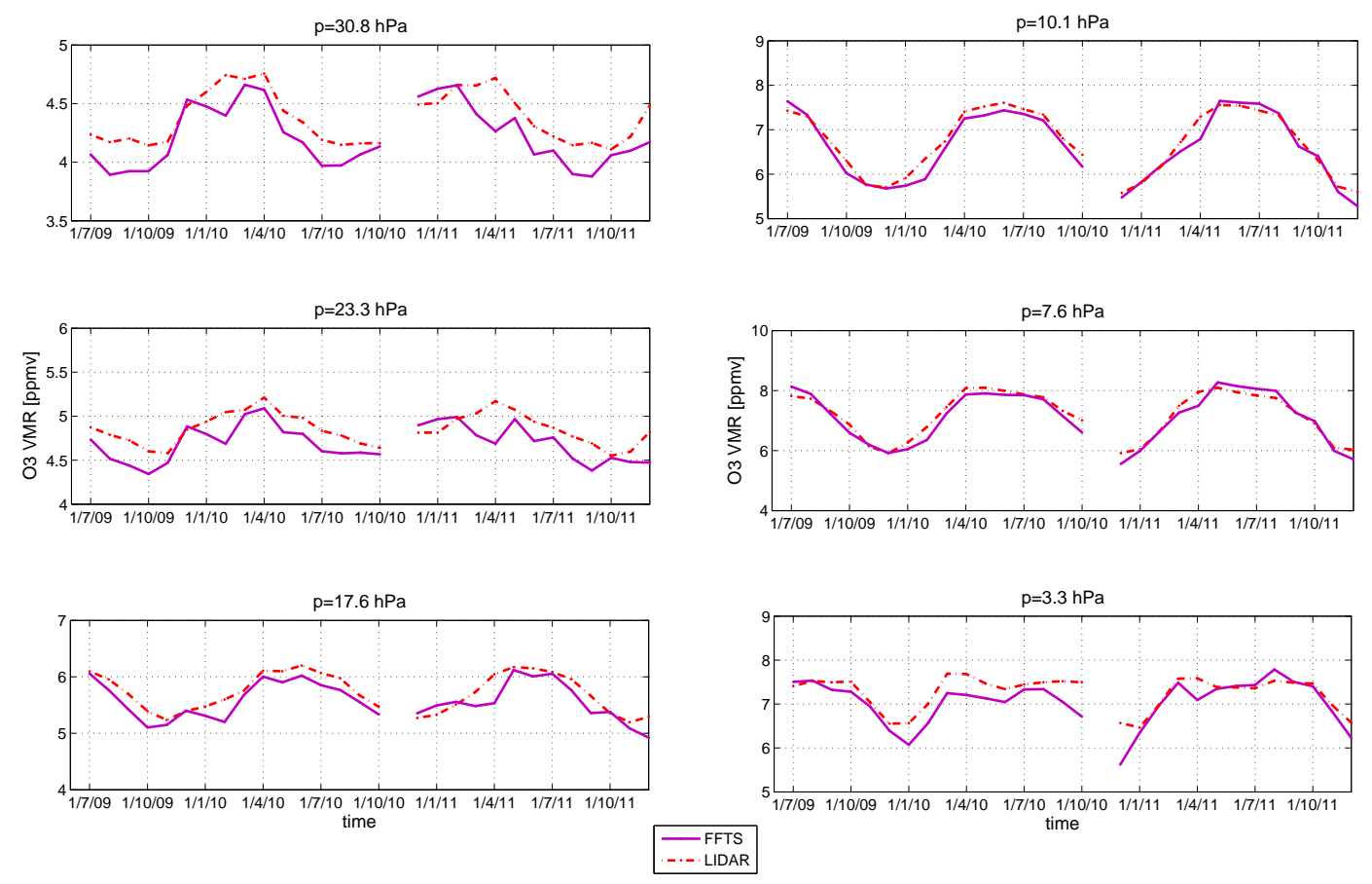

Fig. 7. Ozone time series of coincident GROMOS FFTS (magenta line) and LIDAR (red dashed line) measurements for six pressure levels from July 2009 to December 2011.

\section{Intercomparison of stratospheric ozone profiles}

S. Studer et al.

\section{Title Page}

Abstract

Introduction

Conclusions

References

Tables

Figures

14

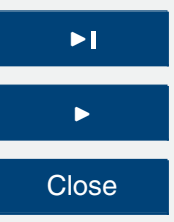

Back

Close

Full Screen / Esc

Printer-friendly Version

Interactive Discussion

(c) (1) 

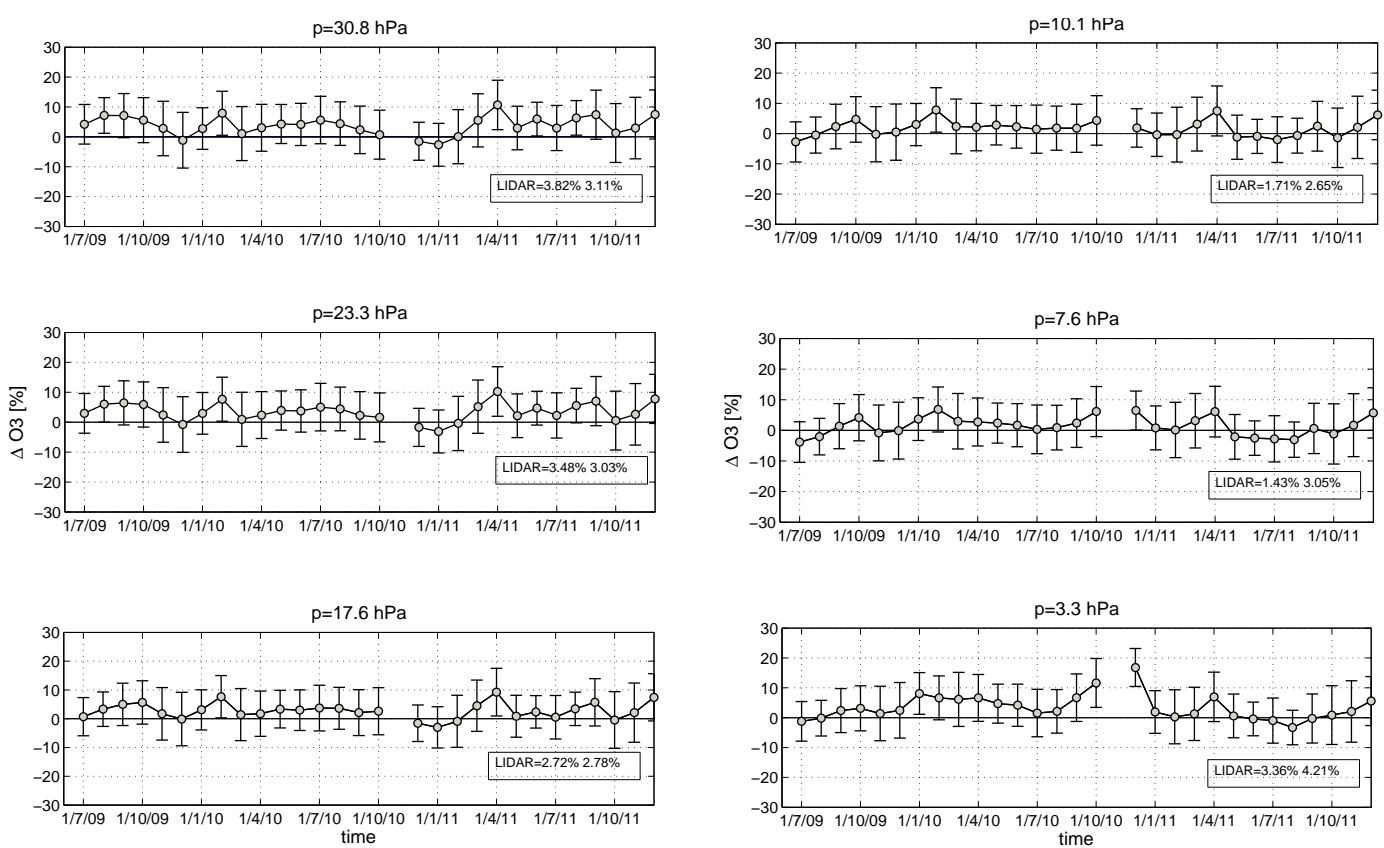

(LIDAR-FFTS)/FFTS

Fig. 8. Time series of relative differences between GROMOS FFTS and LIDAR for July 2009 to December 2011 at six pressure levels. Error bars correspond to the relative standard deviation. In the lower right corner mean differences for the total time period is given.

\section{AMTD}

$6,6097-6146,2013$

Intercomparison of stratospheric ozone profiles

S. Studer et al.

\section{Title Page}

Abstract

Introduction

Conclusions

References

Tables

Figures

14

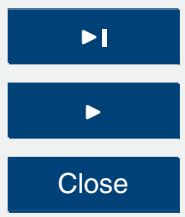

Back

Close

\section{Full Screen / Esc}

Printer-friendly Version

Interactive Discussion 

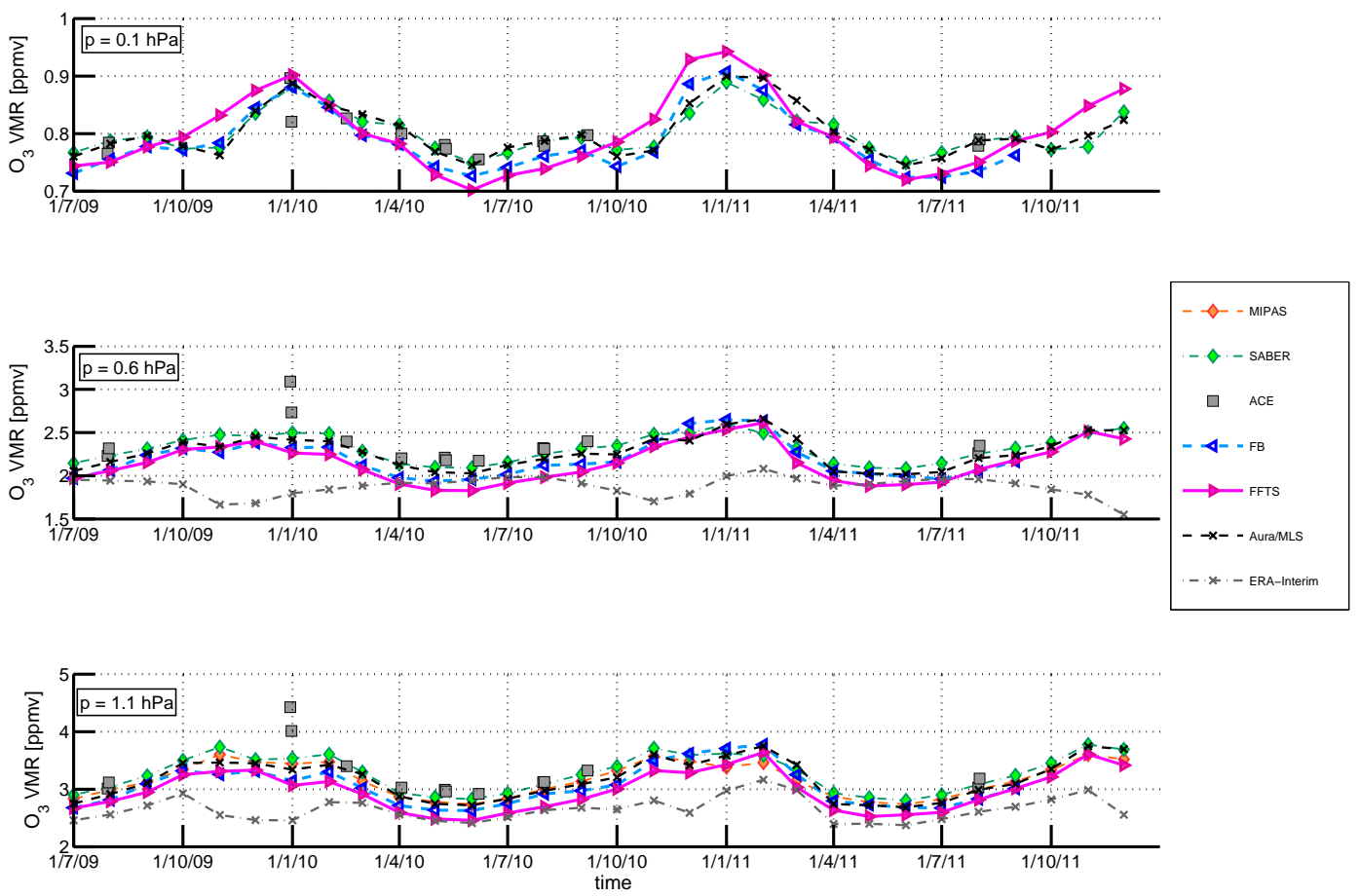

Fig. 9a. Ozone time series of collocations for GROMOS FFTS (magenta line), GROMOS FB (blue line), MIPAS (orange dashed line), SABER (green dashed line), MLS (black dashed line), ERA-Interim (grey dashed line) and ACE-FTS (grey squares) between July 2009 and December 2011 for the lower mesosphere. Upper panel: $0.1 \mathrm{hPa}$. Middle panel: $0.6 \mathrm{hPa}$. Lower panel: $1.1 \mathrm{hPa}$.

\section{AMTD}

$6,6097-6146,2013$

Intercomparison of stratospheric ozone profiles

S. Studer et al.

\section{Title Page}

Abstract

Introduction

Conclusions

References

Tables

Figures

14

$\rightarrow 1$

4

Back

Close

\section{Full Screen / Esc}

Printer-friendly Version

Interactive Discussion 

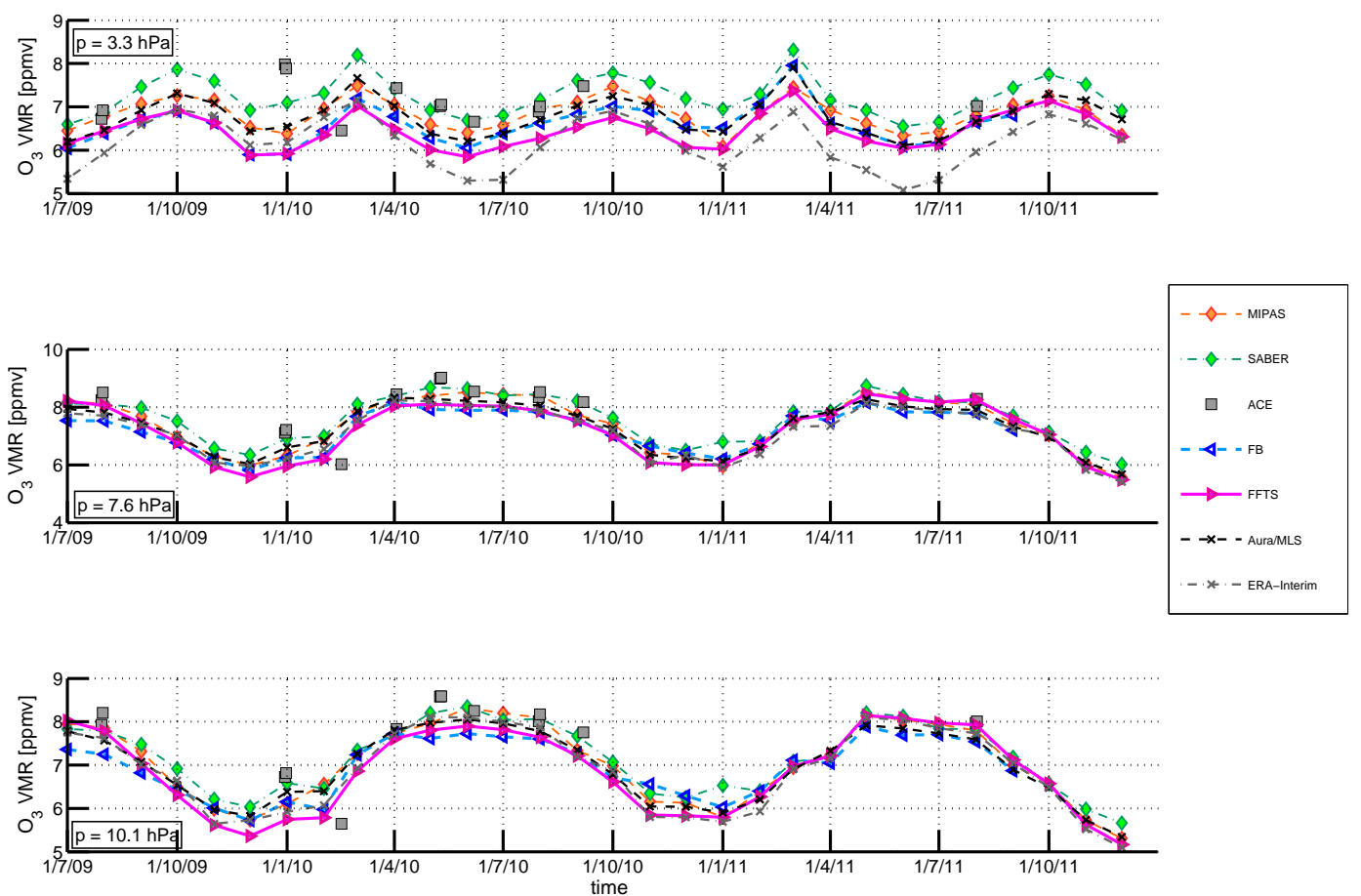

Fig. 9b. Ozone time series of collocations for GROMOS FFTS, GROMOS FB, MIPAS, SABER, MLS, ERA-Interim and ACE-FTS between July 2009 and December 2011 for the upper stratosphere. Upper panel: $3.3 \mathrm{hPa}$. Middle panel: $7.6 \mathrm{hPa}$. Lower panel: $10.1 \mathrm{hPa}$. Color code as in Fig. 9a.

\section{AMTD}

$6,6097-6146,2013$

Intercomparison of stratospheric ozone profiles

S. Studer et al.

\section{Title Page}

Abstract

Introduction

Conclusions

References

Tables

Figures

14

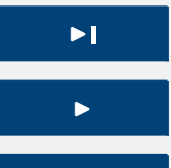

Back

Close

\section{Full Screen / Esc}

Printer-friendly Version

Interactive Discussion

(c) (1) 

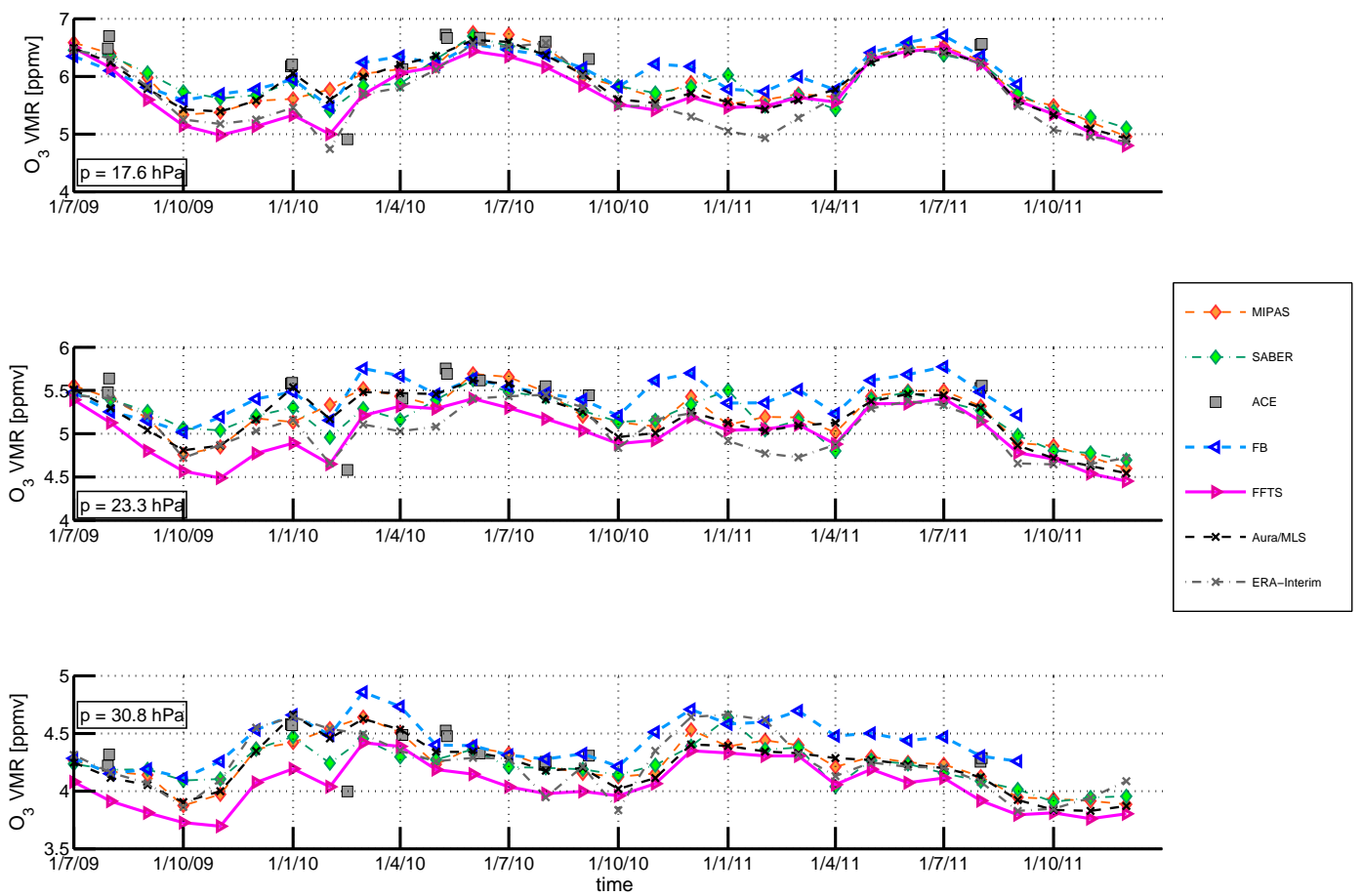

Fig. 9c. Ozone time series of collocations for GROMOS FFTS, GROMOS FB, MIPAS, SABER, MLS, ERA-Interim and ACE-FTS between July 2009 and December 2011 for the lower stratosphere. Upper panel: $17.6 \mathrm{hPa}$. Middle panel: $23.3 \mathrm{hPa}$. Lower panel: $30.8 \mathrm{hPa}$. Color code as in Fig. 9a.

\section{AMTD}

$6,6097-6146,2013$

Intercomparison of stratospheric ozone profiles

S. Studer et al.

\section{Title Page}

\section{Full Screen / Esc}

Printer-friendly Version

Interactive Discussion 


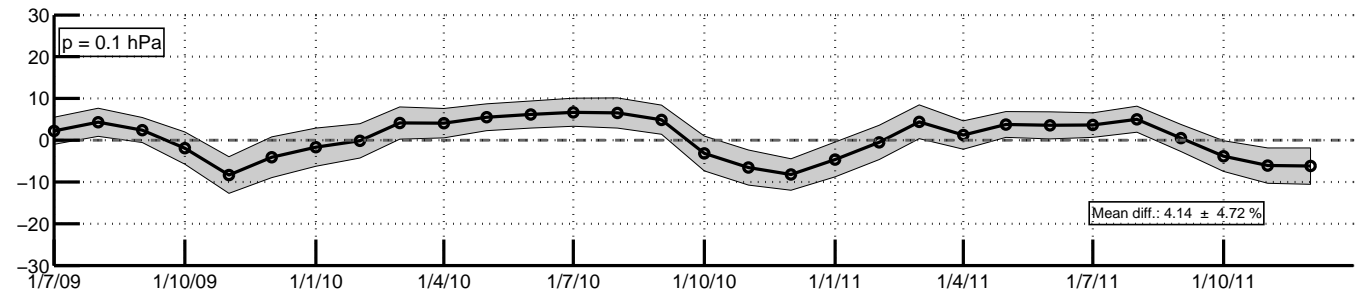

AMTD

6, 6097-6146, 2013

Intercomparison of stratospheric ozone profiles
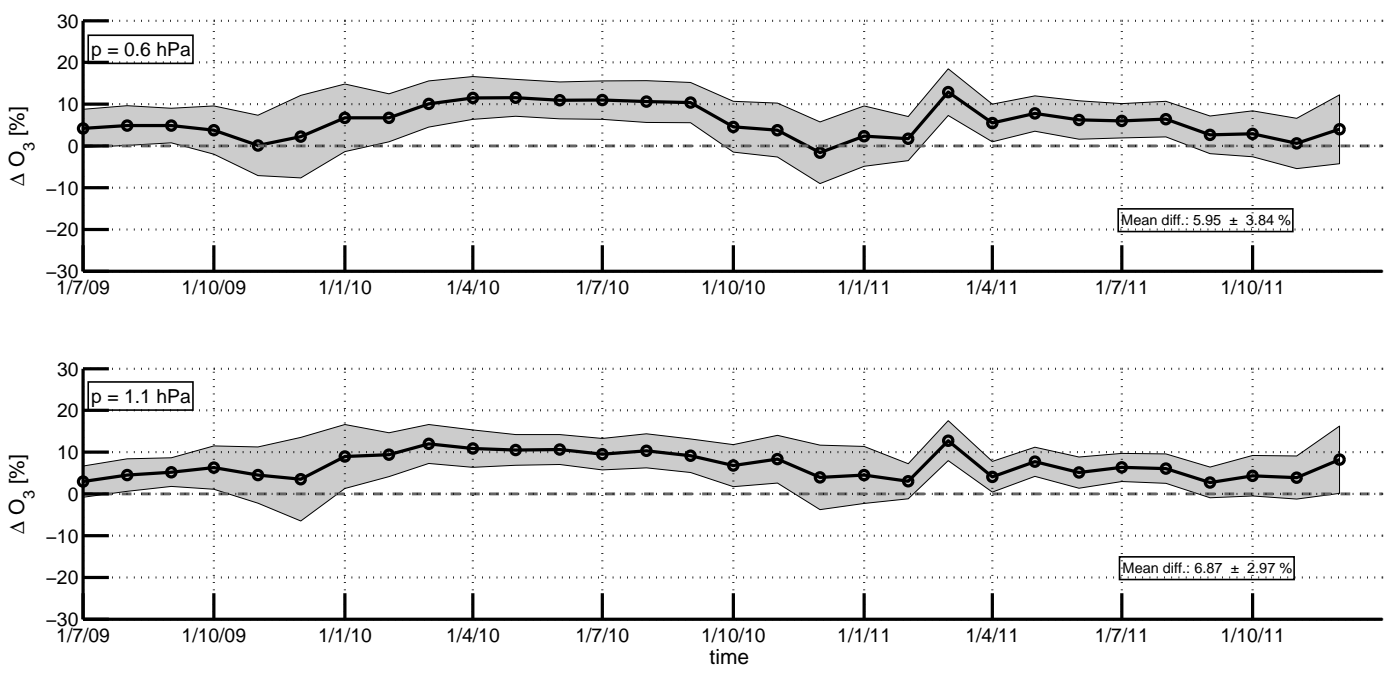

S. Studer et al.

Title Page

Fig. 10a. Time series of relative differences together with the mean standard deviations between GROMOS FFTS and MLS for July 2009 to December 2011 for the lower mesosphere: upper panel: $0.1 \mathrm{hPa}$. Middle panel: $0.6 \mathrm{hPa}$. Lower panel: $1.1 \mathrm{hPa}$. The averaged difference over to whole time period is given in the lower right of the panels.

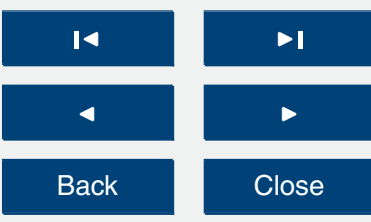

\section{Full Screen / Esc}

Printer-friendly Version

Interactive Discussion 


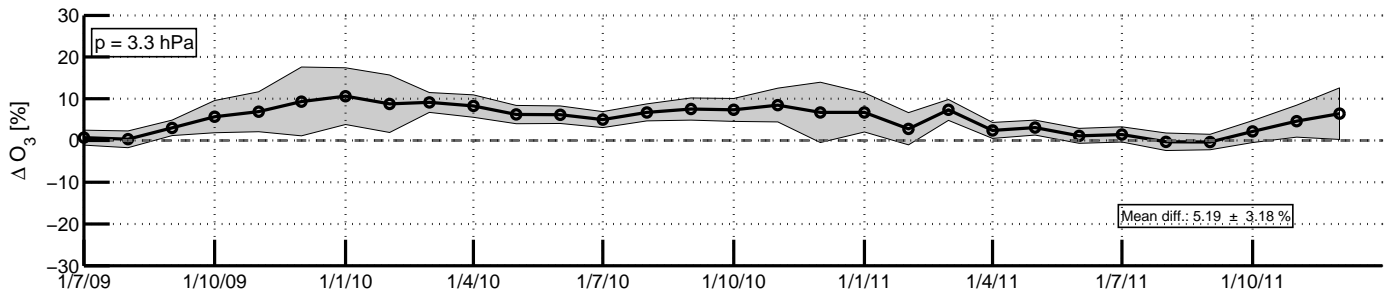

AMTD

$6,6097-6146,2013$

Intercomparison of stratospheric ozone profiles
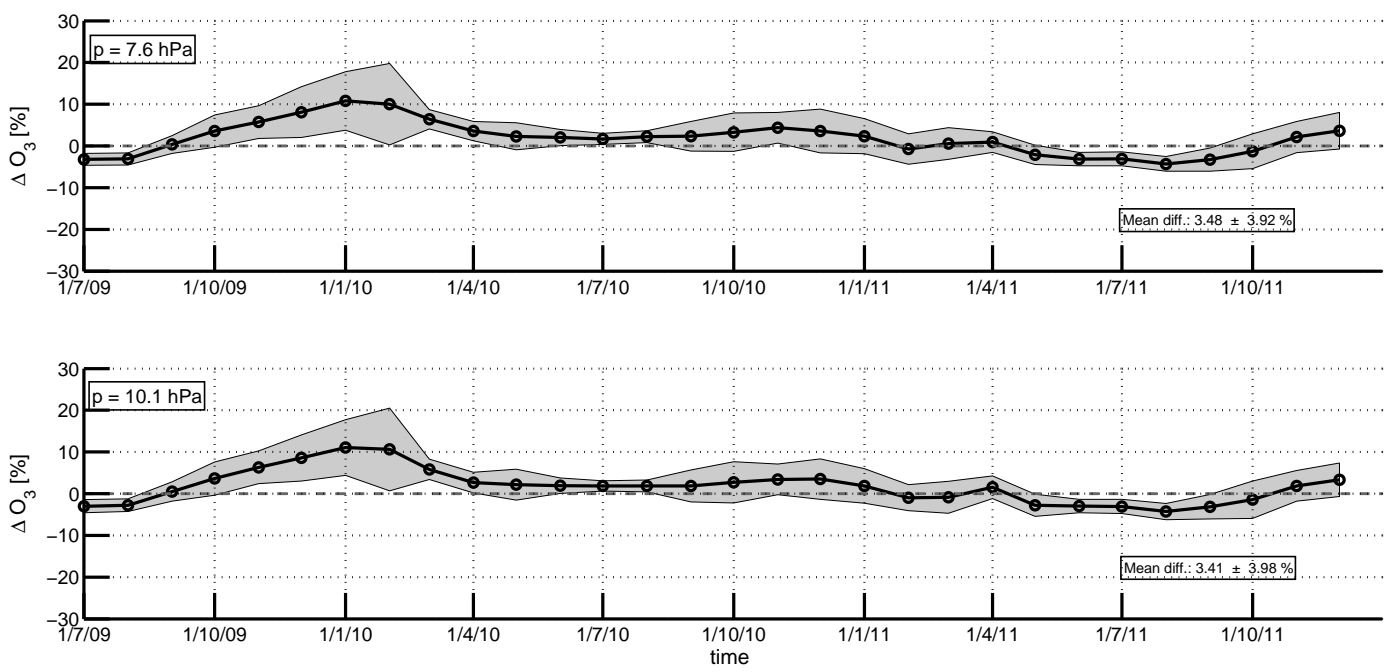

S. Studer et al.

Title Page

Fig. 10b. Time series of relative differences together with the mean standard deviations between GROMOS FFTS and MLS for July 2009 to December 2011 for the upper stratosphere. Upper panel: $3.3 \mathrm{hPa}$. Middle panel: $7.6 \mathrm{hPa}$. Lower panel: $10.1 \mathrm{hPa}$. The averaged difference over to whole time period is given in the lower right of the panels.

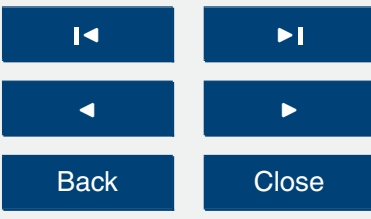

\section{Full Screen / Esc}

Printer-friendly Version

Interactive Discussion 

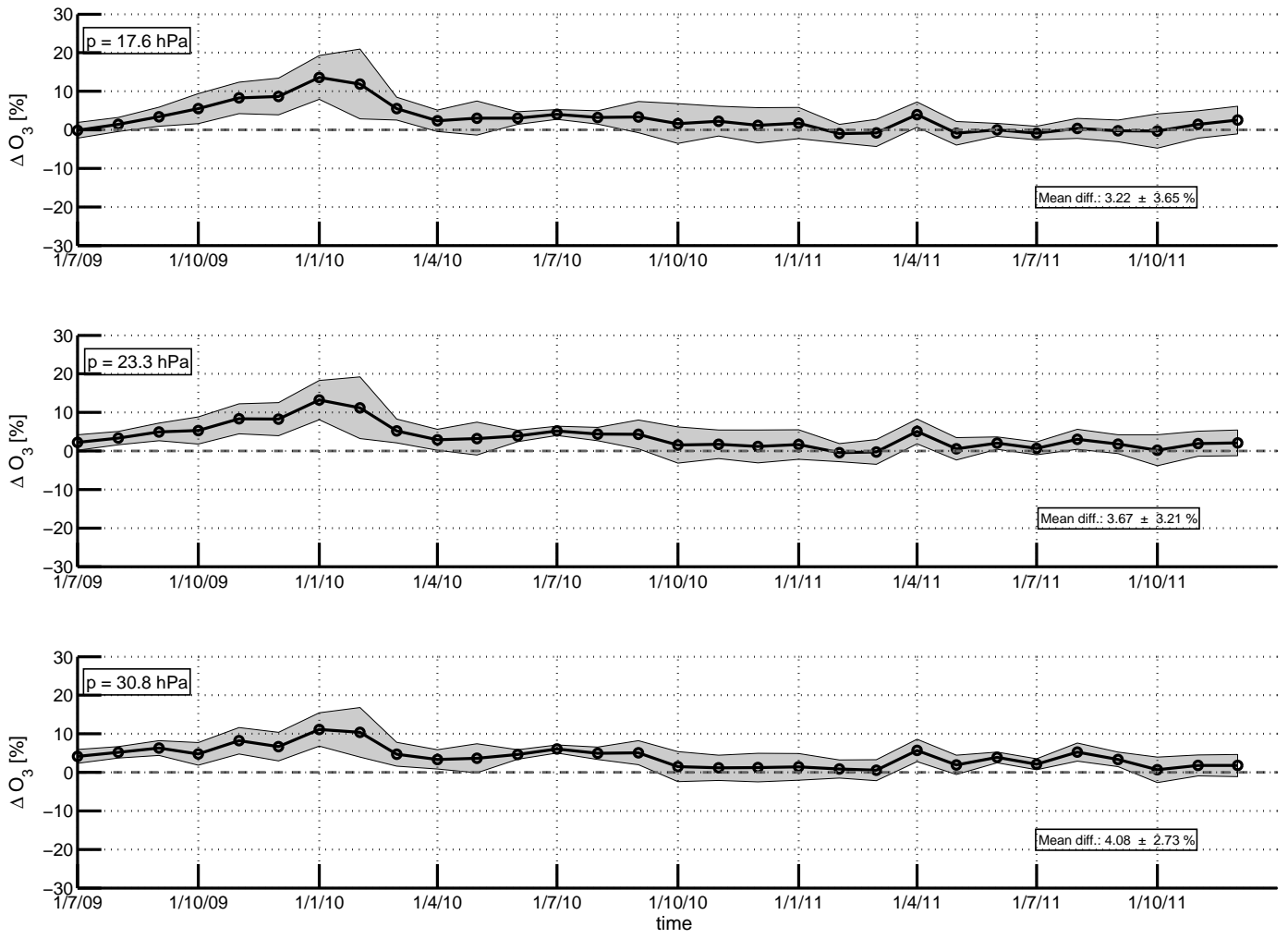

Fig. 10c. Time series of relative differences together with the mean standard deviations between GROMOS FFTS and MLS for July 2009 to December 2011 for the lower stratosphere. Upper panel: $17.6 \mathrm{hPa}$. Middle panel: $23.3 \mathrm{hPa}$. Lower panel: $30.8 \mathrm{hPa}$. The averaged difference over to whole time period is given in the lower right of the panels.

\section{AMTD}

$6,6097-6146,2013$

Intercomparison of stratospheric ozone profiles

S. Studer et al.

\section{Title Page}

Abstract

Introduction

Conclusions

References

Tables

Figures

14

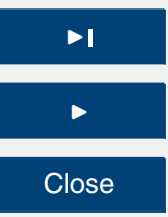

Back

Close

\section{Full Screen / Esc}

Printer-friendly Version

Interactive Discussion 

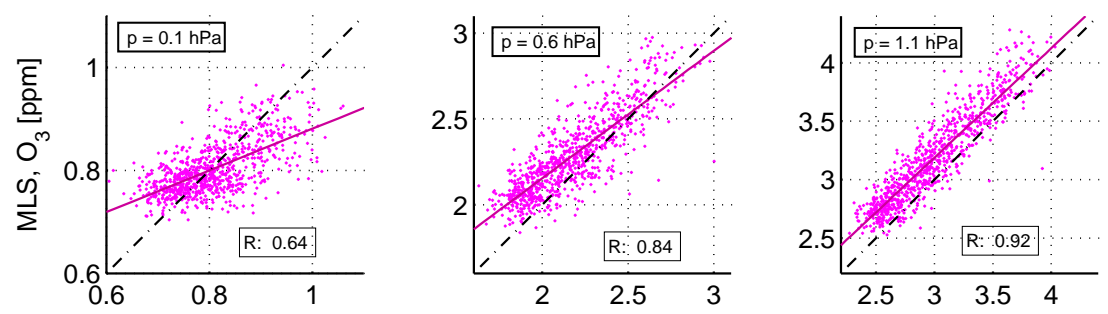

AMTD

$6,6097-6146,2013$

\section{Intercomparison of stratospheric ozone profiles}
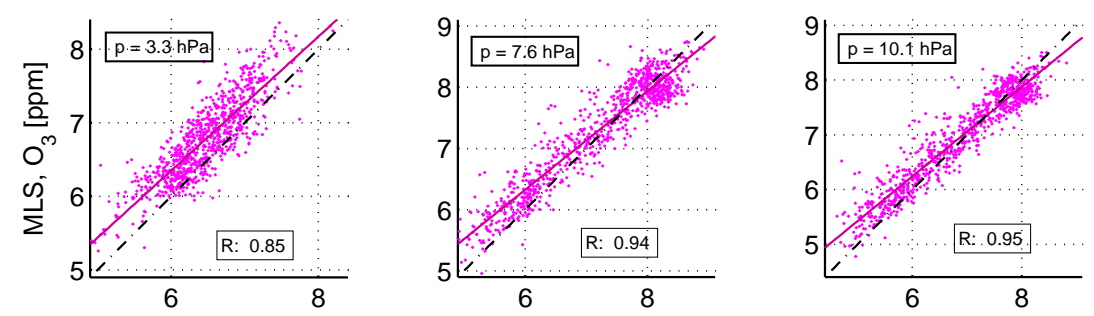

S. Studer et al.

\section{Title Page}

\section{Abstract}

Introduction

Conclusions

References

Tables

Figures
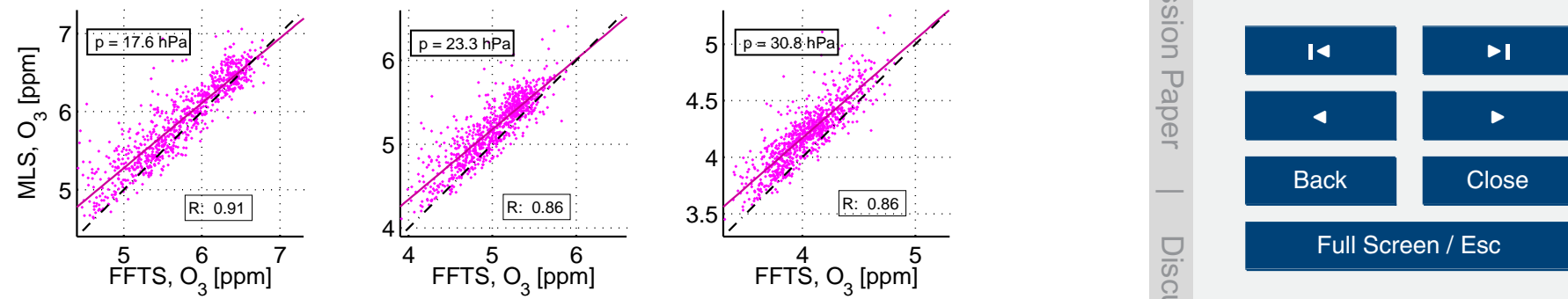

Full Screen / Esc

Fig. 11. Correlation plots of GROMOS FFTS versus MLS volume mixing ratio for different altitudes. The magenta line indicates the linear fit. The black line indicates 1-1. The mean correlation coefficient is given for each altitude. 
GROMOS-FFTS, vK: July 2009 - Dec. 2011

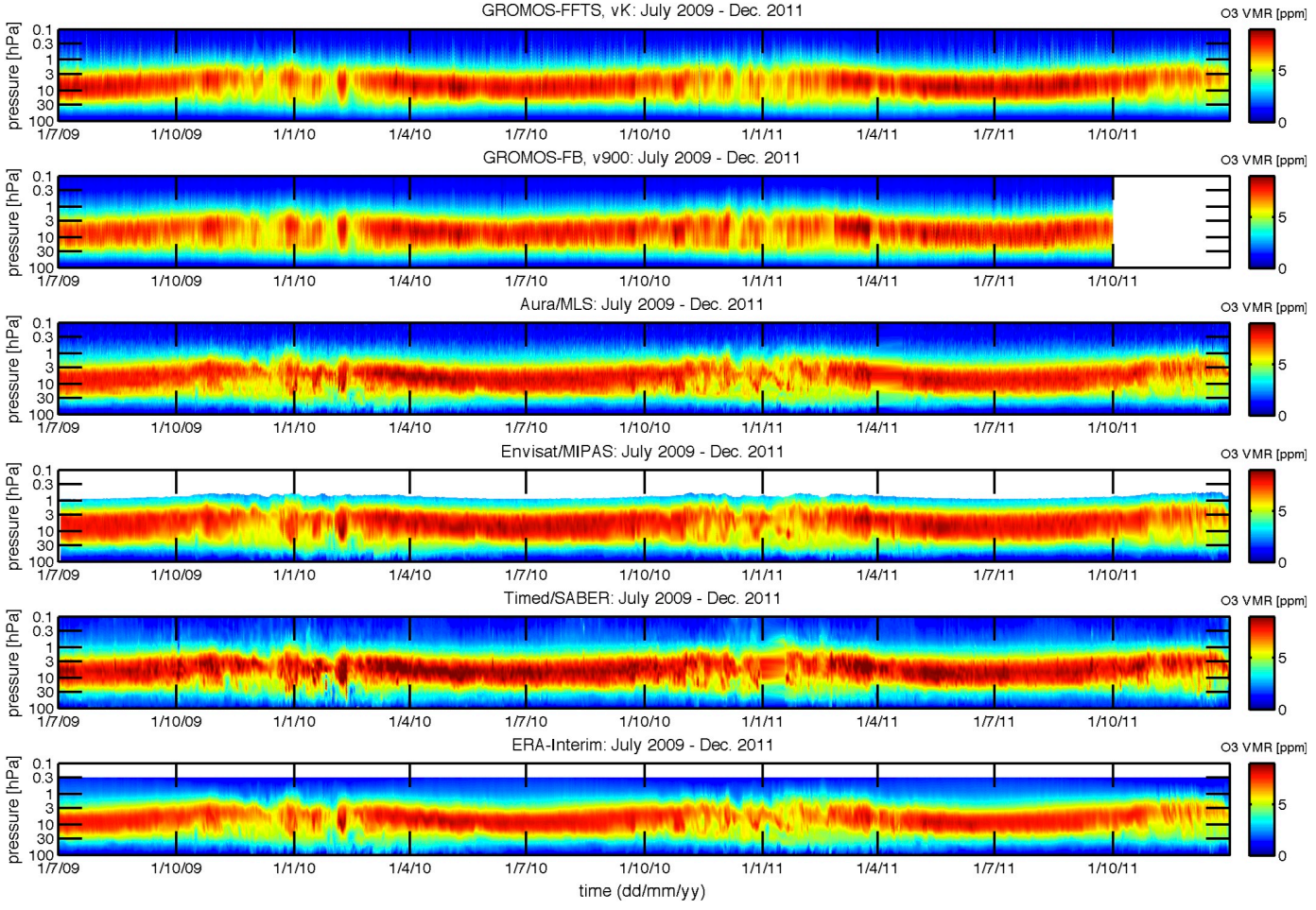

Fig. 12. Time series of collocated ozone volume mixing ratio at fixed pressure levels as observed by GROMOS FFTS, GROMOS FB, MLS, MIPAS, SABER and ERA-Interim from July 2009 to December 2011 (top to bottom panels). Ticks are every three months.

\section{AMTD}

$6,6097-6146,2013$

Intercomparison of stratospheric ozone profiles

S. Studer et al.

\section{Title Page}

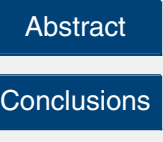

Introduction

References

Tables

Figures

14

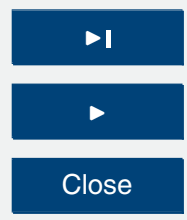

Back

Close

\section{Full Screen / Esc}

Printer-friendly Version

Interactive Discussion 